\title{
8.2 ka BP paleoclimatic event and the Ebro Valley Mesolithic groups: Preliminary data from Artusia rock shelter (Unzué, Navarra, Spain)
}

\author{
Iñigo García-Martínez de Lagrán a, b, *, Eneko Iriarte ${ }^{c}$, Jesús García-Gazólaz ${ }^{\text {d, }}$ \\ Cristina Tejedor-Rodríguez ${ }^{e}$, Juan Francisco Gibaja-Bao ${ }^{\mathrm{f}}$, Marta Moreno-García ${ }^{\mathrm{g}}$, \\ Guillem Pérez-Jordà ${ }^{\mathrm{g}}$, Mónica Ruiz-Alonso ${ }^{\mathrm{g}}$, Jesús Sesma-Sesma ${ }^{\mathrm{d}}$, Rafael Garrido-Pena ${ }^{\mathrm{h}}$, \\ Ángel Carrancho-Alonso ${ }^{i}$, Leonor Peña-Chocarro ${ }^{g, j}$, Manuel A. Rojo-Guerra ${ }^{k}$ \\ ${ }^{a}$ University of the Basque Country, U.P.V./E.H.U. IT622-13 Research Group in Prehistory, Basque Research System, Spain \\ ${ }^{\mathrm{b}}$ Laboratoire TRACES UMR5608, Université de Toulouse Le Mirail 2, France \\ ${ }^{c}$ Human Evolution Laboratory, Department of Historical Sciences and Geography, University of Burgos, I+D+i Building, Burgos, Spain \\ d Institution Prince of Viana, Government of Navarre, Spain \\ e Arcadia Institute, General Foundation of the University of Valladolid, Spain \\ ${ }^{\mathrm{f}}$ Milà i Fontanals Institute, Department of Archaeology and Anthropology, Spanish National Research Council, Barcelona, Spain \\ ${ }^{g}$ Archaeobiology Group, Department of Archaeology and Social Processes, Institute of History, \\ Spanish National Research Council (CCHS-CSIC), Madrid, Spain \\ ${ }^{\mathrm{h}}$ Department of Prehistory and Archaeology, Autonomous University of Madrid, Spain \\ ${ }^{i}$ Area of Prehistory, Department of Historical Sciences and Geography, University of Burgos, $I+D+i$ Building, Burgos, Spain \\ j Spanish School of History and Archaeology in Rome, Spanish National Research Council, Rome, Italy \\ ${ }^{\mathrm{k}}$ Department of Prehistory and Archaeology, University of Valladolid, Spain
}

\section{A R T I C L E I N F O}

Article history:

Available online $\mathrm{xxx}$

\section{Keywords:}

Mesolithic

8.2 ka BP abrupt climatic event

Fluvial tufa

Upper Ebro Basin

Iberian Peninsula

\begin{abstract}
A B S T R A C T
This paper presents the results of the first excavation campaign of the Artusia rock shelter in Unzué, Navarre, Spain. Chronocultural and archaeobiological analyses revealed five different occupation phases (Artusia I-V) within the regional Mesolithic timeline, specifically in the Mesolithic of Notches and Denticulates (Artusia I and II) and the Geometric Mesolithic (Artusia III, IV, and V). In addition, the study of the sedimentological and palaeoenvironmental evolution in the entire record helped to clearly define several climatic events which developed around $6550 \mathrm{cal} \mathrm{BC}-8500 \mathrm{cal}$ BP and $6250 \mathrm{cal} \mathrm{BC}-8200 \mathrm{cal}$ BP. Here, we present a description of these events and their (pre)historical interpretation with the aim of recognizing how they influenced the Mesolithic hunter-gatherer groups living in the Ebro Basin of the Iberian Peninsula.
\end{abstract}

() 2015 Elsevier Ltd and INQUA. All rights reserved.
Lydia Zapata, in memoriam

\section{Introduction}

In recent decades, the study of the Mesolithic in the Iberian Ebro Valley has focused mainly on the definition of different phases in accordance with the lithic industry as well as on the publication of several time series. Questions relating to subsistence and environment have also been addressed which results suggest an intense, planned and diversified type of exploitation and economy. The publication of a variety of monographs on particular sites (Barandiarán-Maestu, 1978: Botiquería dels Moros; Barandiarán-

\footnotetext{
* Corresponding author.

E-mail address: igmtzl@gmail.com (I. García-Martínez de Lagrán).
}

Maestu and Cava-Almuzara, 1989: Costalena; Alday-Ruiz, 1998: Kanpanoste Goikoa; Barandiarán-Maestu and Cava-Almuzara, 2001: Aizpea; Cava-Almuzara, 2004b: Kanpanoste Goikoa: UtrillaMiranda and Rodanés, 2004: Los Baños; Alday-Ruiz, 2006a: Mendandia; Utrilla-Miranda and Mazo, 2014: Forcas II; etc.), and the organisation of monographic congresses on two of the different phases (Alday-Ruiz, 2006b: Mesolithic of Notches and Denticulates; Utrilla-Miranda and Montes-Ramírez, 2009: Geometric Mesolithic) indicate the increased interest in these issues.

However, aspects related to palaeoclimatic and palaeoenvironmental changes and their influence on the historical evolution of Mesolithic groups have only been tackled in recent years (González-Sampériz et al., 2008, 2009; Utrilla-Miranda et al., 2009; García-Martínez de Lagrán, 2012). From this perspective, the data obtained on the Artusia rock shelter help to reinitiate the 
debate, even to amplify it, as they shed light not only on the palaeoenvironmental changes occurred ca. 8200 cal BP. The palaeoenvironmental data from several analyses, together with radiocarbon dates and the study of archaeological materials allow construction of an unusually clear picture of the $8.2 \mathrm{ka}$ BP event and its consequences for the evolution of these societies.

\section{Archaeological site: discovery and geographical framework}

The Artusia rock shelter is located at Unzué, a small village in the eastern part of Navarre, in the Valdorba region (Fig. 1). This archaeological site was discovered in 1996, and the preservation problems that this rock shelter faces due to the erosion derived by the Artusia stream are highlighted. Artusia is located, as are many other Mesolithic rock shelters from the southern Pyrenean slope, on a rock face, to which morphology refers its name in Basque (Arluxea $=$ long crag). It is located at the southern slope of a narrow pass that the Artusia stream excavated between the Alaiz Mountains on the north, and the Unzué Crag on the south (Fig. 1). The rock shelter is filled by a stratigraphic package cut lengthwise by the stream that exposes the different archaeological levels which form most of the sequence (Figs. 2 and 3).

The area where Artusia is situated represents the geological, climatic, floristic and politico-administrative border between the pre-Pyrenean Pamplona Basin and the Ebro Valley (FloristánSamanes, 1995: 450). The transitional nature of this area was surely valued by prehistoric settlers. Two other factors could also be considered of importance for these ancient populations: i) its proximity to one of the main communication routes between the mountains and the Ebro River Valley which has been used through millennia as pathway (Royal cañada, Royal Road, railway, national road and motorway) and ii) the possibility of quick access to two distinct biotopes, the Alaiz Mountains in the north, peaking at 1100-1150 m.a.s.l., and the glacis formations of El Carrascal foothills in the south and the west. The area currently has a subMediterranean continental climate, showing a clear asymmetry between the northern side of the Alain Mountains, with strong Atlantic influence, and the southern side, where the site is located, with a sunny microclimate. The average annual rainfall ranges from 450 to $1100 \mathrm{~mm}$ and the temperature between 11 and $14^{\circ} \mathrm{C}$. The peculiar microclimate of the rock shelter is due to its location on the sunny southern side.

The archaeological work carried out in the Artusia rock shelter was a rescue excavation due to danger of collapse. It was promoted by the Institution Prince of Viana, Government of Navarre and the two short archaeological campaigns conducted during 2009 and 2010 were directed by Dr. Manuel Rojo Guerra (Dept. Prehistory, University of Valladolid, Spain).

\section{Data and results}

The two campaigns undertaken on the Artusia rock shelter were conditioned by the site peculiarities. The main goals were: i) to recover part of the sedimentary sequence in danger of collapse and ii) to recognize in detail the rock shelter stratigraphy. With this purpose, the excavation focused on three different parts of the stratigraphic package (Figs. 2 and 3):

- Sector A: located on the southern part of the site presents a stratigraphic sequence $\sim 5 \mathrm{~m}$ deep. The deepest part is underneath the riverbed. The excavated surface was uneven, ranging between 0.5 and $3 \mathrm{~m}^{2}$.

- Sector B: on the central part of the sedimentary package, it is $3.5 \mathrm{~m}$ deep. A $50 \mathrm{~cm}$-width strip was dug with the aim of obtaining a thorough understanding of the stratigraphy that will allow interpretation in conjunction with Sectors A and $C$.

- Sector C: located on the northern part of the site, it is the area most affected by erosive processes and danger of collapse. In the 2009, campaign an approximate surface of $0.5 \mathrm{~m}^{2}$ and $3 \mathrm{~m}$ depth was excavated; while in the 2010 campaign the surface was enlarged, reaching $1.5 \mathrm{~m}^{2}$ and $1.5 \mathrm{~m}$ depth.

A total of 124 stratigraphic units were documented during the excavation. They form a superposition of up to five phases archaeologically framed during the Mesolithic, and with several occupational phases.

\subsection{Archaeostratigraphy}

\subsubsection{Artusia I - 1st phase of the Mesolithic of Notches and Denticulates}

This is the oldest occupational phase in Artusia, and it is documented in Sector A only, the sector with the deepest excavated profile (Fig. 3). However, it is envisaged that this occupational phase was also present in the other parts of the rock shelter. This phase is characterised by a rich level (SU 65) that extends under the riverbed. Abundant faunal and flint remains were recovered together with charcoal remains derived from successive human occupations. The last of these occupations left several hearths (SU 58,61 ) on SU 65 that are characterised by a succession of ashes, rubefacted red areas, and abundant charcoal.

Both the lithics found in these stratigraphic units and the radiocarbon dates obtained in SU 65 (Context: Occupation level; Sample: Corylus charcoal; Beta-374433: $8260 \pm 40$ BP; 7461-7145 cal BC, 9410-9093 cal BP, Table 1, Figs. 3 and 10) indicate that Artusia I is framed within the Mesolithic of Notches and Denticulates (Alday-Ruiz, 2006b).

Table 1

Mesolithic of Notches and Denticulates and Geometric Mesolithic dates in the Ebro Basin.

\begin{tabular}{|c|c|c|c|c|c|c|}
\hline \multicolumn{7}{|c|}{ Mesolithic of Notches \& Denticulates } \\
\hline \multirow[t]{2}{*}{ Start } & $1 \sigma$ & \multicolumn{5}{|c|}{$9712-9470$} \\
\hline & $2 \sigma$ & \multicolumn{5}{|c|}{$9902-9402$} \\
\hline \multirow[t]{2}{*}{ End } & $1 \sigma$ & \multicolumn{5}{|c|}{$6506-6357$} \\
\hline & $2 \sigma$ & \multicolumn{5}{|c|}{$6563-6223$} \\
\hline Context & Lab. & $\mathrm{BP}$ & \pm & cal BC-2 $\sigma^{\mathrm{a}}$ & Sample & Ref. \\
\hline \multirow[t]{3}{*}{ Agut $4.7 c$} & OxA-10050 & 10085 & 60 & $9752-9331$ & Charcoal & Vaquero-Rodríguez (2006) \\
\hline & OxA-10074 & 10060 & 65 & 9729-9319 & Charcoal & Vaquero-Rodríguez (2006) \\
\hline & OxA-10051 & 9895 & 60 & $9624-9251$ & Charcoal & Vaquero-Rodríguez (2006) \\
\hline Agut $4.7 \mathrm{a}$ & OxA-10049 & 9185 & 60 & $8555-8286$ & Charcoal & Vaquero-Rodríguez (2006) \\
\hline \multirow[t]{2}{*}{ Ángel $18 d$} & GrA-22826 & 8390 & 60 & $7577-7326$ & Charcoal & Montes-Ramírez et al. (2006) \\
\hline & GrN-15518 & 8060 & 70 & $7287-6701$ & Charcoal & Montes-Ramírez et al. (2006) \\
\hline Ángel 2 2b & GrN-22836 & 8310 & 60 & $7517-7183$ & Charcoal & Montes-Ramírez et al. (2006) \\
\hline Artusia I & Beta-374433 & 8260 & 40 & $7461-7145$ & Charcoal & Unpublished \\
\hline
\end{tabular}


Table 1 (continued)

\begin{tabular}{|c|c|c|c|c|c|c|}
\hline \multicolumn{7}{|c|}{ Mesolithic of Notches \& Denticulates } \\
\hline Artusia II & Beta-374432 & 7790 & 40 & $6689-6507$ & Charcoal & Unpublished \\
\hline \multirow[t]{3}{*}{ Atxoste V } & GrA-13448 & 8030 & 50 & $7082-6709$ & Bone & Alday-Ruiz (2006a,b) \\
\hline & GrA-13472 & 7830 & 50 & $6906-6508$ & Bone & Alday-Ruiz (2006b) \\
\hline & GrA-13447 & 7810 & 40 & $6751-6511$ & Bone & Alday-Ruiz (2006b) \\
\hline Atxoste VI & GrA-13473 & 8840 & 50 & $8210-7757$ & Bone & Alday-Ruiz, 2006b \\
\hline Atxoste VI & GrA-15699 & 8760 & 50 & $8166-7606$ & Bone & Alday-Ruiz (2006b) \\
\hline Atxoste VI & GrA-15700 & 8510 & 80 & $7721-7361$ & Bone & Alday-Ruiz (2006b) \\
\hline \multirow[t]{2}{*}{ Balma Guilanyá C } & Beta-186168 & 9410 & 60 & $9112-8490$ & Charcoal & Martínez-Moreno et al. (2006) \\
\hline & Beta-185064 & 8680 & 50 & $7933-7587$ & Charcoal & Martínez-Moreno et al. (2006) \\
\hline \multirow[t]{2}{*}{ Baños 2b1 } & GrA-24556 & 8040 & 50 & $7137-6769$ & Charcoal & Montes-Ramírez et al. (2006) \\
\hline & GrA-21552 & 7740 & 50 & $6650-6473$ & Charcoal & Montes-Ramírez et al. (2006) \\
\hline \multirow[t]{3}{*}{ Berroberría B } & GrN-18424 & 8800 & 80 & $8211-7646$ & Bone & Alday-Ruiz (2006b) \\
\hline & GrN-18422 & 8580 & 80 & $7821-7484$ & Bone & Alday-Ruiz (2006b) \\
\hline & GrN-16619 & 8470 & 80 & $7612-7331$ & Bone & Alday-Ruiz (2006b) \\
\hline \multirow[t]{2}{*}{ Berroberría C } & GrN-18426 & 8630 & 70 & $7934-7537$ & Bone & Alday-Ruiz (2006b) \\
\hline & GrN-16618 & 8510 & 90 & $7735-7352$ & Bone & Alday-Ruiz (2006b) \\
\hline \multirow[t]{2}{*}{ Filador 2} & OxA-8658 & 8515 & 50 & $7601-7500$ & Charcoal & García-Argüelles Andreu and Fullola-Pericot (2006) \\
\hline & AA-13411 & 8150 & 90 & $7456-6829$ & Charcoal & García-Argüelles Andreu and Fullola-Pericot (2006) \\
\hline Forcas II Ib & Beta-59997/CAMS-535 & 8650 & 70 & $7938-7570$ & Charcoal & Montes-Ramírez et al. (2006) \\
\hline Kanpanoste Goikoa III-inf & GrN-20215 & 7620 & 80 & $6639-6403$ & Bone & Alday-Ruiz (2006b) \\
\hline Kanpanoste Lanh-s & GrN-22440 & 7620 & 70 & $6630-6406$ & Bone & Alday-Ruiz (2006b) \\
\hline Kanpanoste Lanh-i & GrN-22441 & 8200 & 70 & $7451-7059$ & Bone & Alday-Ruiz (2006b) \\
\hline La Cativera A & AA-23367 & 7979 & 60 & $7055-6696$ & Charcoal & Vaquero-Rodríguez (2006) \\
\hline \multirow[t]{2}{*}{ Legunova 1} & Gra-22086 & 8250 & 60 & $7468-7083$ & Charcoal & Montes-Ramírez et al. (2006) \\
\hline & GrA-24292 & 8200 & 50 & $7351-7066$ & Charcoal & Montes-Ramírez et al. (2006) \\
\hline Legunova 2 & GrA-24294 & 8800 & 60 & $8205-7662$ & Charcoal & Montes-Ramírez et al. (2006) \\
\hline \multirow[t]{2}{*}{ Mendandia IV } & GrN-22744 & 7810 & 50 & $6802-6502$ & Bone & Alday-Ruiz (2006a) \\
\hline & GrN-22715 & 7780 & 40 & $6680-6506$ & Bone & Alday-Ruiz (2006a) \\
\hline Molí del Salt sup & Beta-173335 & 8040 & 40 & $7082-6813$ & Bone & Vaquero-Rodríguez (2006) \\
\hline \multirow[t]{2}{*}{ Peña 14 b } & GrN-25998 & 8000 & 90 & $7162-6649$ & Charcoal & Montes-Ramírez et al. (2006) \\
\hline & GrN-25999 & 8000 & 80 & $7133-6656$ & Charcoal & Montes-Ramírez et al. (2006) \\
\hline \multicolumn{7}{|l|}{ Geometric Mesolithic } \\
\hline \multirow[t]{2}{*}{ Start } & $1 \sigma$ & $6830-6692$ & & & & \\
\hline & $2 \sigma$ & $6954-6655$ & & & & \\
\hline \multirow[t]{2}{*}{ End } & $1 \sigma$ & $5431-5296$ & & & & \\
\hline & $2 \sigma$ & $5461-5194$ & & & & \\
\hline Context & Lab. & $\mathrm{BP}$ & \pm & cal BC-2 $\sigma$ & Sample & Ref. \\
\hline \multirow[t]{2}{*}{ Ángel $18 c$} & GrA-27278 & 7955 & 45 & $6861-6643$ & Charcoal & Utrilla-Miranda et al. (2009) \\
\hline & GrA-27274 & 7435 & 45 & $6408-6229$ & Charcoal & Utrilla-Miranda et al. (2009) \\
\hline Ángel 2 2a & Beta-254048 & 6390 & 40 & $5474-5328$ & Bone & Utrilla-Miranda et al. (2009) \\
\hline \multirow[t]{2}{*}{ Aizpea I } & GrN-16620 & 7790 & 70 & $6749-6471$ & Bones & Barandiarán-Maestu and Cava-Almuzara (2001) \\
\hline & GrN-16621 & 7160 & 70 & $6211-5904$ & Bones & Barandiarán-Maestu and Cava-Almuzara (2001) \\
\hline Aizpea II & GrN-16622 & 6830 & 70 & $5876-5622$ & Bones & Barandiarán-Maestu and Cava-Almuzara (2001) \\
\hline & GrA-779 & 6600 & 50 & $5621-5481$ & Human bone & Barandiarán-Maestu and Cava-Almuzara (2001) \\
\hline Atxoste IV & GrA-13469 & 7480 & 50 & $6435-6243$ & Bone & Alday-Ruiz and Cava-Almuzara (2009) \\
\hline & GrA-13418 & 7340 & 50 & $6359-6071$ & Bones & Alday-Ruiz and Cava-Almuzara (2009) \\
\hline Artusia III & Beta-374431 & 7680 & 40 & $6598-6453$ & Charcoal & Unpublished \\
\hline Artusia V & Beta-379670 & 7210 & 30 & $6205-6009$ & Charcoal & Unpublished \\
\hline Atxoste IIIb2 & GrA-13415 & 6940 & 40 & $5967-5730$ & Bones & Alday-Ruiz and Cava-Almuzara (2009) \\
\hline Botiquería dels Moros 2 & GrA-13265 & 7600 & 50 & $6587-6386$ & Cervus & Barandiarán-Maestu and Cava-Almuzara (2000) \\
\hline Botiquería dels Moros 4 & GrA-13267 & 6830 & 50 & $5833-5633$ & Bone & Utrilla-Miranda et al. (2009) \\
\hline Cabezo de la Cruz UE 1398 & GrN-29135 & 7150 & 70 & $6210-5893$ & Charcoal & Rodanés-Vicente and Picazo Millán (2009) \\
\hline Forcas II II & GrN-22686 & 7240 & 40 & $6214-6029$ & Charcoal & Utrilla-Miranda et al. (2009) \\
\hline & Breta-250944 & 7150 & 40 & $6082-5922$ & Bone & Utrilla-Miranda et al. (2009) \\
\hline Kanpanoste Goikoa III & GrN-20214 & 6360 & 70 & $5485-5296$ & Bones & Alday-Ruiz and Cava-Almuzara (2009) \\
\hline Los Baños 2b1 & GrN-21552 & 7740 & 50 & $6649-6472$ & Charcoal & Utrilla-Miranda et al. (2009) \\
\hline Los Baños 2b3inf & GrA-21551 & 7550 & 50 & $6481-6257$ & Charcoal & Utrilla-Miranda et al. (2009) \\
\hline Los Baños 2b3sup & GrA-21550 & 7350 & 50 & $6362-6079$ & Charcoal & Utrilla-Miranda et al. (2009) \\
\hline Mendandia IIIinf & GrN-22743 & 7620 & 50 & $6590-6411$ & Bones & Alday-Ruiz (2006a) \\
\hline Peña 14 a & GrN-25094 & 7660 & 90 & $6681-6372$ & Charcoal & Utrilla-Miranda et al. (2009) \\
\hline Pontet e & GrN-16313 & 7340 & 70 & $6377-6063$ & Charcoal & Utrilla-Miranda et al. (2009) \\
\hline
\end{tabular}

a The calibrated values are the result of the OxCal 4.2 Overlapping phases function. (https://c14.arch.ox.ac.uk/).

\subsubsection{Artusia II -2nd phase of the Mesolithic of Notches and Denticulates}

From a stratigraphic point of view, this is the thickest occupational phase in Artusia, reaching more than $2 \mathrm{~m}$ (Fig. 3). The stratigraphic units show recurring human occupations, most likely of seasonal character. The presence of occupation floors and hearths and the materials recovered indicate that these human occupations were very intense. There are several examples with overlapping hearths and large quantities of flint and faunal remains.

Some of these hearths (SU 30, 33, 38, etc.) seem to be on the occupation floors. In other cases, these structures were identified within the occupational floor sediment levels, such as a hearth (SU 35) in SU 32 or another (SU 49) in SU 48 (Fig. 3). In general, both the 


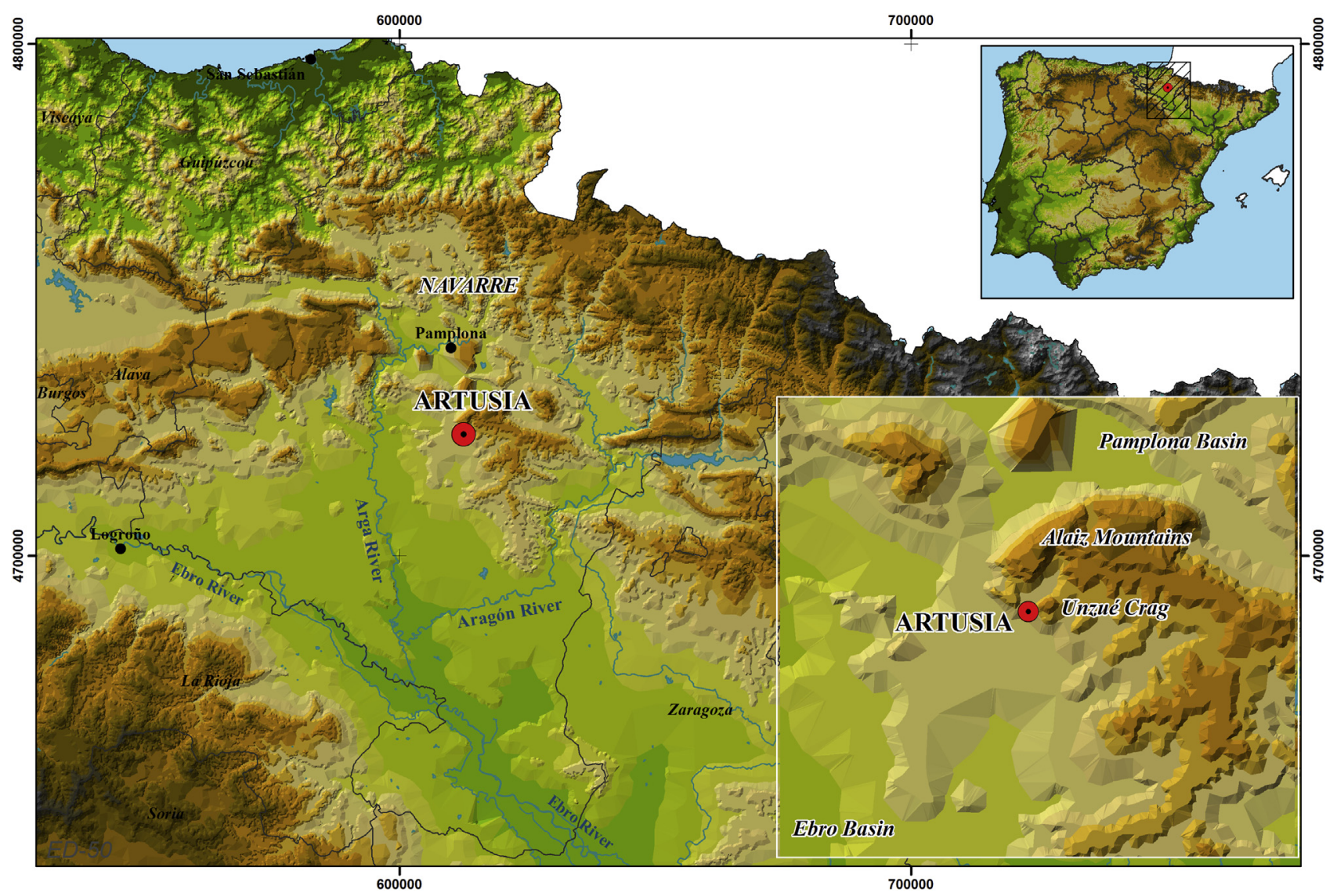

Fig. 1. Location of Artusia rock shelter.

occupational levels and the hearths share a number of features. The former present different coloured layers due to the varying occurrence of carbonate tufa facies sedimentation. In particular, SU 56 stands out as it is a level with abundant tufa framestones and without archaeological materials. This persists in the following phase (Artusia III). Another common feature of the occupational levels is the varying presence of charcoal and archaeological remains.

The hearths show a succession of layers with charcoal, ashes, and rubefacted carbonate sediments (SU 33). Sometimes, below the rubefacted sediment, there appears a layer of compacted yellowish carbonate sediments that could be interpreted as the set-up of the structure (SU 25, 28, 30, 38). Occasionally, these hearths showed a pebble layer surrounding or filling the structure (SU 35, 49). As in the previous phase, the lithics and a radiocarbon date in SU 30 (Context: Hearth; Sample: Pinus sp. charcoal; Beta-374432: $7790 \pm 40$ BP; 6689-6507 cal BC, 8638-8457 cal BP, Table 1, Figs. 3 and 10) frame Artusia II within the Mesolithic of Notches and Denticulates (Alday-Ruiz, 2006b).

\subsubsection{Artusia III - 1st phase of the Geometric Mesolithic}

From a stratigraphic and sedimentological point of view, this phase has the features of the previous phase (Fig. 3). In general, the characteristics of the occupation layers and the hearths are the same. However, in Artusia III the occupations seem to be less intense than in Artusia II. The amount of recovered materials and the number of structures as well as their features diminish: in many cases they are just charcoal accumulations. Additionally, carbonate sedimentation is much more frequent, determining the sedimentological features and, most likely the prehistoric occupation of Artusia.

The main difference with the previous phase relates to the appearance of geometric microliths in the lithic industry. The radiocarbon date of SU 20 (Context: Hearth/Charcoal accumulation; Sample: Corylus charcoal; Beta-374431: $7680 \pm 40$ BP; 6598-6453 cal BC, 8547-8402 cal BP, Table 1, Figs. 3 and 10) and the presence of geometric microliths place this phase within the regional Geometric Mesolithic (Utrilla-Miranda and MontesRamírez, 2009).

\subsubsection{Artusia IV -2nd phase of the Geometric Mesolithic}

From SU 9 to 18 in Sector A and SU 69 in Sector B and SU 3 in Sector $C$ respectively hard tufa, difficult to excavate, was found. The archaeological and structural remains are very scarce.

In those units, neither diagnostic materials nor radiocarbon dates are present, just charcoal and faunal remains. It seems that the occupations were less intense or the site was abandoned at this time. The inclusion of Artusia IV within the Geometric Mesolithic is determined by its stratigraphic location between phases III and V (Utrilla-Miranda and Montes-Ramírez, 2009).

\subsubsection{Artusia $V-3 r d$ phase of the Geometric Mesolithic}

The last phase in which Artusia was occupied corresponds to SU 2, 8 and 68, as well as to the hearth SU 100. It was detected in Sectors B and C only (Fig. 3). This phase shows similar features to previous phases regarding the formation and content of the occupational floors (archaeological materials, charcoal) and the hearth typology (succession of charcoal, ash and rubefacted base surrounded by a layer of pebbles). Both archaeological materials and a 


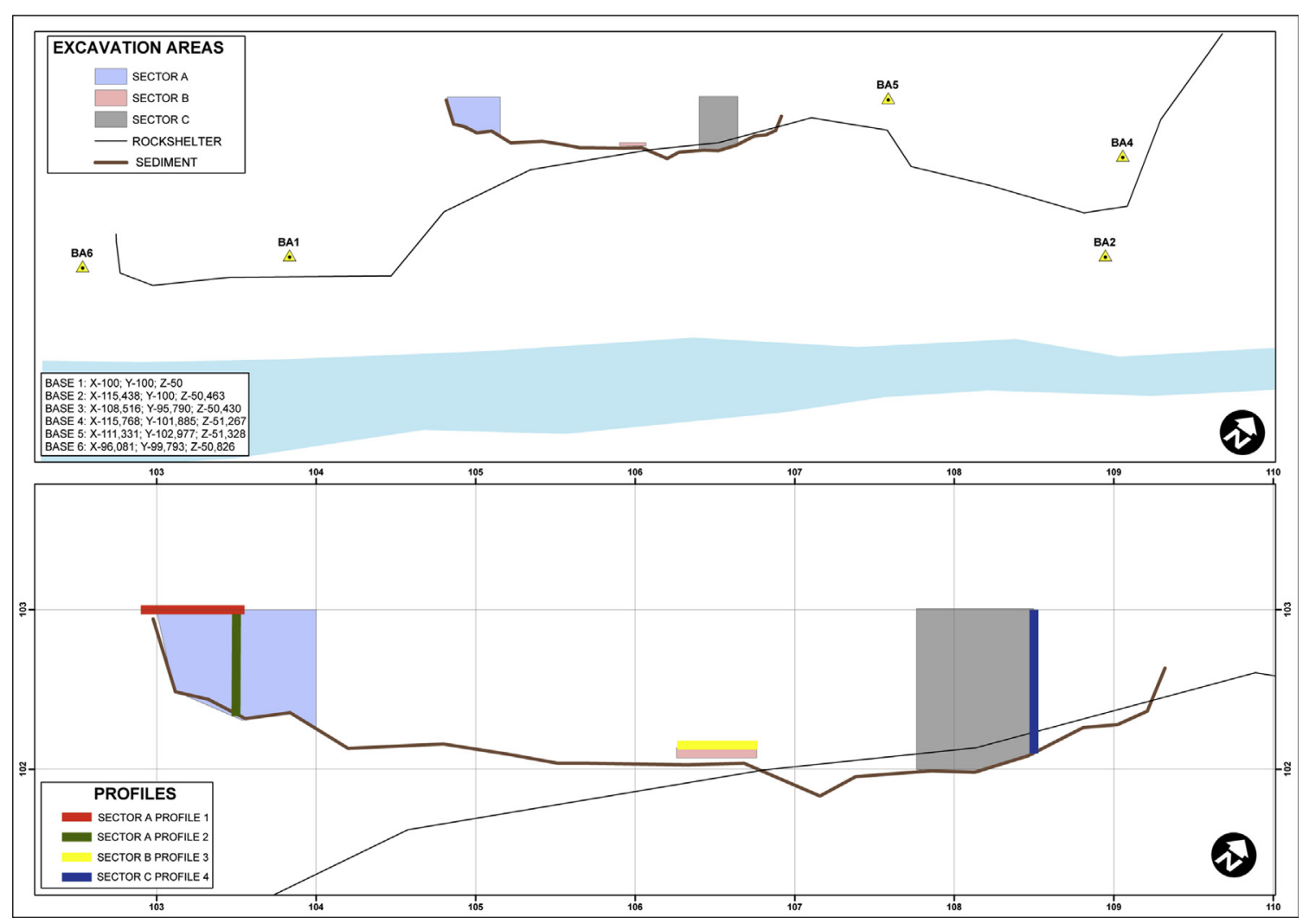

Fig. 2. General mapping of the site and of the excavations areas (Coordinates in meters).

radiocarbon date (Context: Occupation level; Sample: Fraxinus sp. Charcoal; Beta-379670: $7210 \pm 30$ BP; 6205-6009 cal BC, 8154-7958 cal BP, Table 1, Figs. 3 and 10) frame this phase within the Geometric Mesolithic (Utrilla-Miranda and Montes-Ramírez, 2009).

In summary, the stratigraphy in the Artusia rock shelter shows that hunter-gatherer groups repeatedly occupied this site, likely seasonally, during the Mesolithic. However, the intensity of these occupations was different among the identified phases. During the occupation periods, inhabitants developed occupation soils with excavated hearths, some surrounded by pebbles. This type of occupation is similar to that described in nearby, contemporaneous archaeological sites.

\subsection{Lithostratigraphy and site formation processes}

Artusia is encompassed in a carbonate tufa terrace that was formed due to the aggradational evolution of a barraged fluvial tufa system (Pedley, 1990, 2009). Subsequent erosional processes related to changes in the water availability produced the incision and the formation of a valley-side perched outcrop that is $3.5 \mathrm{~m}$ above the modern Artusia river channel.

In this section, the main stratigraphic and sedimentological features of the depositional sequence outcropping at the Artusia site are described and the different sedimentary processes leading to its formation are discussed. The sedimentary sequence was divided into eight lithostratigraphic units according to its sedimentary facies (Fig. 4).

Unit 1 includes the basal $100 \mathrm{~cm}$ of the sequence in Sector A. It is composed of a basal layer of dark silty clay sediments with abundant archaeological remains, especially bone fragments and charcoal (SU 65). This unit lies directly on the limestone substrate and reach up to $70 \mathrm{~cm}$ thick. It has a massive fabric with scattered centimetric limestone clasts and bioturbation features. Carbonate precipitates cement porosity (bioturbation). Above, a tufaceous unit of intraclastic and microdetritic wackestone facies (SU 60) includes terrigenous aggregates of the previous unit and includes a well preserved hearth (Fig. 5b). Above this unit, a $\sim 25 \mathrm{~cm}$ thick layer of red silt with abundant charcoal fragments was deposited, including a well-preserved hearth surrounded by limestone clasts (SU 40) (Fig. 5a). The porosity is carbonate-cemented due to periodic events of carbonate saturated water floods that led to a progressive flooding of the area and the sedimentation of the overlying tufa unit (Fig. 5c).

Unit 1 is interpreted to include floodplain sediments, clays and silts, encompassing numerous archaeological remains derived from intense human occupation. The basal dark unit (SU 65) is interpreted as a sequence of amalgamated aggrading palaeosols, with intense human occupation. The overlaying tufaceous sediments (SU 60 ) indicate an increasing frequency of flooding events, indicated by the presence of a silty unit (SU40) that is finally replaced by tufaceous sediments of Unit 2. The change from terrigenous siliciclastic to tufaceous carbonate sedimentation indicates an increasing input of karst water to the Artusia River.

Unit 2 is composed of $\sim 25 \mathrm{~cm}$ of tufa sediments in Sector A (overlying Unit 1) and in the base of Sector B; in the later outcrop, it lies on the limestone substrate (Figs. 4 and $5 \mathrm{c}$ ). The sediments are mainly composed of centimetric layers of microdetritic and intraclastic wackestone with abundant gastropod shell fragments (Fig. 4, L.U. 2-Facies 1; Fig. 5d). Centimetre-thick crusts, phytoherm framestones (Fig. 4, L.U. 2-Facies 4) are also present. Near the top, root bioturbation and dispersed charcoal fragments are visible.

Unit 2 represents the onset of a barraged valley bottom fluvial tufa system (Pedley, 1990, 2009). The tufa sediments correspond to allochthonous intraclastic detrital input from the erosion and transport of tufa precipitates upstream, and autochthonous 


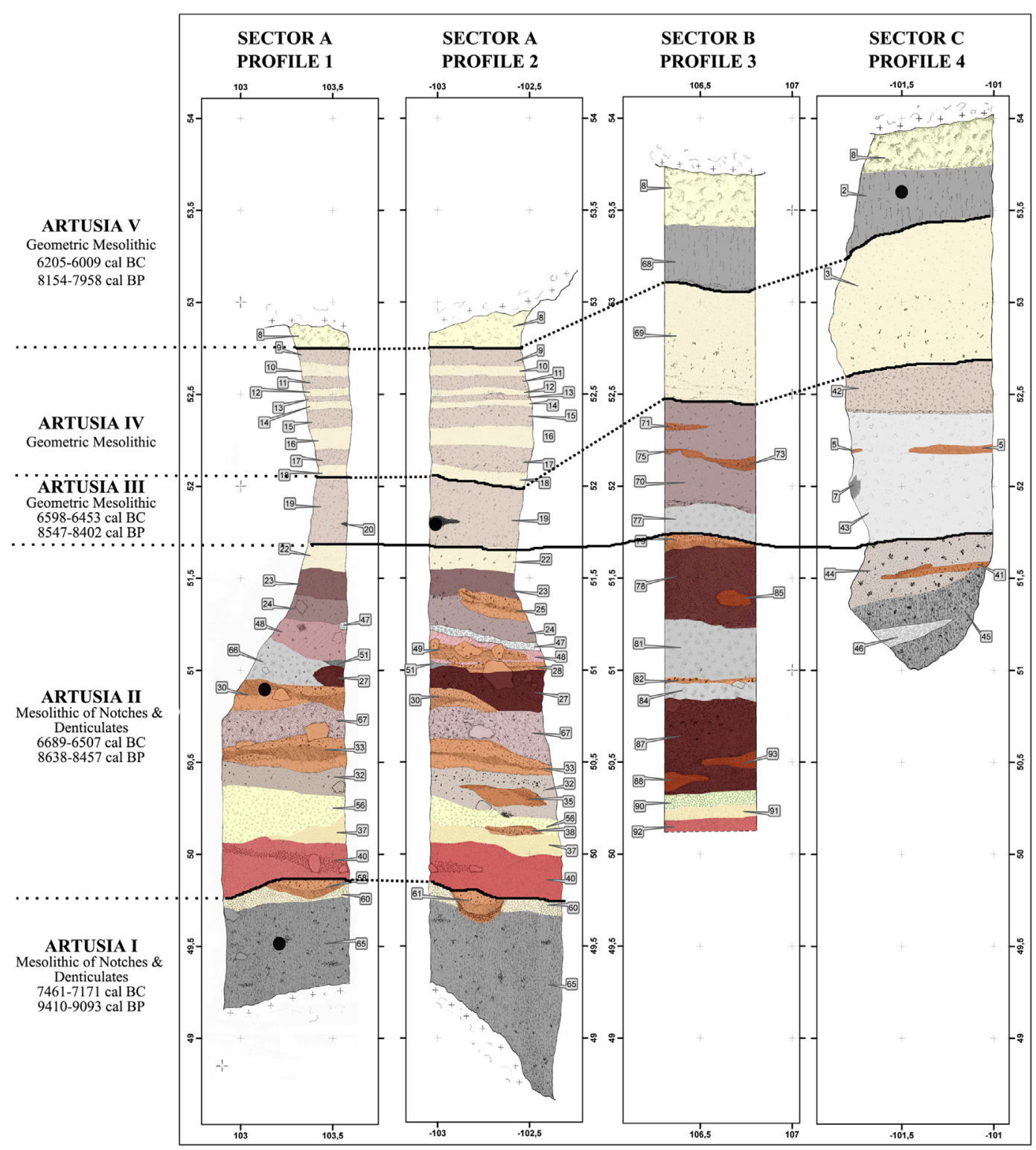

Fig. 3. Artusia rock shelter profiles with the definition of the different phases and the location of the dated samples (black points).

carbonates are formed from encrusted accumulations of plant remains and the formation of stromatolitic phytoherms (Fig. 5c). The allochthonous sedimentary phases were episodic, deposited mostly during high-water events, indicating a possible seasonality in the waterflow.

Unit 3 is composed of $\sim 40 \mathrm{~cm}$ of fine tufa sediments, intraclastic and microdetritic wackestones (Fig. 4, L.U. 3-Facies 1), similar to those of Unit 1. However, they have a higher content of up to centimetric charcoal and ash fragments, including abundant interbedded centimetric rubefacted red levels (Fig. 4, L.U. 3-Facies 2; Fig. 5e) that sometimes are overlaid by ash and charcoal layers, filling excavated hearths. This unit has abundant archaeological remains.

Unit 3 reflects the cyclical deposition of sediments in a pooled area of the river. Intraclastic allochthonous sediment was deposited mainly in high-water conditions. The depositional sequence was systematically interrupted by drier periods, where the archaeological area would emerge. In these relatively low-water periods is when human occupation is attested by the presence of numerous amalgamated excavated hearths, with rubefacted bottoms and coal and ash layers, as well as other archaeological remains (bone, lithic industry, etc.). The abundant presence of human occupation levels show a high frequency alternation of high-water humid and lowwater drier periods, probably seasonal, the human occupations made possibly during summer.

Unit 4 is composed of $\sim 20 \mathrm{~cm}$ of limestone and phytoclast framestone gravels up to $5 \mathrm{~cm}$ in diameter, with an intraclastic grainstone-packstone matrix (Fig. 4. L.U. 4-Facies 3). It has an erosive basal contact that erodes the underlying Unit 3. The gravel layers form fining upwards sequences that finish with the sedimentation of intraclastic laminated tufa layers with abundant bioclastic fragments (gastropods) (Fig. 4, L.U. 4-Facies 1). The archaeological content is relatively low and does not contain rubefacted levels.

Unit 4 is interpreted as the amalgamation of channel-filling sequences. The deposition of high-energy channel facies 
crosscutting and eroding relatively deeper facies (dammed pools) of Unit 3 denotes a lowering of the water table and the subsequent incision of the river channel through previous tufa sediments.

Unit 5 is $\sim 95 \mathrm{~cm}$ thick, and is mainly composed of intraclastic and microdetritic wackestone facies (Fig. 4, L.U. 5-Facies 1 ) with abundant charcoal, ash and rubefacted tufa clasts. It includes abundant rubefacted levels (Fig. 4, L.U. 5-Facies 2) originated due to the presence of excavated hearths with occasional infill of in situ charcoal and ash. The facies 1 and 2 layers pass laterally into few centimetre-thick and decimetre-scale wide channels filled with limestone granules and intraclastic finer sediment.

Unit 5 is similar to unit 2; the presence of intraclastic fine tufa sediments point to a low energy allochthonous detrital input deposited in pooled areas. In low-water seasons, the margins of the pooled area were subaerially exposed, and the waterflow formed small channels. The repeated settling of human groups during the deposition of this unit led to a sequence of amalgamated hearths of almost $1 \mathrm{~m}$ thick.

Unit 6 comprises $\sim 120 \mathrm{~cm}$ of intraclastic and microdetritic wackestone tufas (Fig. 4, L.U. 6-Facies 1) with interbedded centimeter-thick carbonate phytoherm framestones (Fig. 4, L.U. 6Facies 4). This unit includes scarce charcoal and ash fragments (Fig. 5f).

The sediments of unit 6 reflect a fluvial pooled area with autochthonous tufa sedimentation of phytoherm framestone crusts (Facies 4) that episodically received allochthonous sediments (Facies 1). This sedimentation denotes submerged conditions almost continuously, indicating wetter conditions that previous lithostratigraphic units. The presence of scattered charcoal fragments could denote the presence of human occupation areas in nearby emerged areas.

Unit 7 is composed of $\sim 25 \mathrm{~cm}$ of dark intraclastic and microdetritic tufa wackestone (Fig. 4). It has a high organic matter content and abundant archaeological remains (Fig. $5 \mathrm{~g}$ ). The structure is massive with abundant root bioturbation filled by carbonate cement.

Unit 7 represents a layer of edaphized tufa (facies 1 and 4) that forms a palaeosol. The enrichment in organic matter and the presence of root bioturbation point to the formation of a superficial A horizon, that embedded successive amalgamated human occupation remains (Dabkowski, 2014). This unit indicates a cessation in the tufa sedimentation, subaerial exposure, and vegetation colonization of the surface that was also occupied by humans. This processes point to a sudden drop in the karst water inflow and the phreatic level that led to the incision of previous tufa sediments.

Unit 8 is composed of $\sim 25 \mathrm{~cm}$ of phytoherm framestone tufa with abundant scattered archaeological remains (fragments of charcoal, bone, etc.) (Fig. 4). This level clogs the accommodation space under the limestone shelter, constituting the last sediments deposited on the tufa terrace.

Unit 8 represents the reactivation of the tufa sedimentation, the rise of the water table and the formation of phytohrem framestones. This unit overlies the paleosol forming the Unit 7, and demonstrates the episodic nature of the water table drop and soil formation.

\subsection{Lithic industries}

\subsubsection{Typology and technology}

The total amount of elements documented in the lithic industry is 1815 pieces (Table 2), all made of flint, which is mostly local, from a $10 \mathrm{~km}$ procurement area around the site. This is a common pattern amongst the Mesolithic habitats of the Upper Ebro Basin.
Table 2

Lithic remains in Artusia rockshelter.

\begin{tabular}{lccccr}
\hline & $\begin{array}{l}\text { Artusia } \\
\text { I - MN\&D }\end{array}$ & $\begin{array}{l}\text { Artusia } \\
\text { II - MN\&D }\end{array}$ & $\begin{array}{l}\text { Artusia } \\
\text { III - GM }\end{array}$ & $\begin{array}{l}\text { Artusia } \\
\text { V - GM }\end{array}$ & Total \\
\hline Endscraper & 1 & & 6 & 1 & 8 \\
Burin & 2 & & & & 2 \\
Driller & 1 & 1 & & 1 & 3 \\
Notched tools & 3 & 5 & 3 & 3 & 14 \\
$\begin{array}{l}\text { Denticulate } \\
\text { Truncated tools }\end{array}$ & 4 & 7 & 1 & 1 & 13 \\
Geometric & & & & 2 & 2 \\
Microburins & & & & 4 & 10 \\
Scraper & 3 & 2 & & 1 & 2 \\
Chipped piece (ecaillé) & 1 & 1 & & & 6 \\
Total tools & 15 & 16 & 16 & 15 & 62 \\
Knapping & 246 & 566 & 193 & 146 & 1151 \\
Total remains & 261 & 582 & 209 & 161 & 1213 \\
\hline
\end{tabular}

One third of the lithic assemblage comes from Chronological Horizon 6, in which the significant postdepositional alterations observed clearly diminish the quality of the data. We recovered 1213 items attributable to four chronocultural horizons identified throughout the sequence (Artusia I, II, III and V) (Table 2, Fig. 6).

3.3.1.1. Mesolithic of Notches and Denticulates. The two time horizons belonging to this phase (Artusia I and II) are characterised by the use of direct percussion for exploitation in the site itself with local small-sized flint nodules/tablets, greatly determining the products obtained. The type repeatedly sought is a $3 \mathrm{~cm}$ long by $2 \mathrm{~cm}$ wide flint flake which is $5 \mathrm{~mm}$ thick. These cores are the base of the tools made, and in over $60 \%$ of the cases, are used to make notches and denticulates. To this end, extensive retouches consisting of discontinued lines are often used, sometimes deep retouch with step terminations and frequently inverse and alternate. The need for maximum use of the flint means that many of these tools are made from fragments of flakes, pointing to a constant reutilisation of the bases, as well as the probable breaking up of the flakes as a result of the exploitation of the nodules or nuclei in order to obtain a greater number of cores. Also significant is the presence of the cortex in a large number of tools. Many of the features noted in Artusia are shared by other contemporary settlements such as Kanpanoste Goikoa, Kanpanoste, Atxoste and Mendandia in Alava, Berroberría, Aizpea in Navarre, or Peña 14 and Legunova in neighbouring Aragon (Fig. 13).

3.3.1.2. Geometric Mesolithic phase. There is no doubt that the geometric bases, their design and technology, characterise this final Mesolithic process. In Artusia, despite the scarcity of assemblages, a certain evolution in types can be appreciated between the two phases detected. In the older of the geometric phases, concavebased trapezes predominate (Fig. 6c: 14-17), whereas in the final phase, the one completing the site's sequence, scalene-type triangles appear, particularly the ogive-type, the so-called Tardenois (Fig. 6d: 19-21), with a simple retouch on its base. This evolution was previously detected in another site in the Upper Ebro Basin, the Mesolithic settlement of the Aizpea Rock Shelter (Fig. 13), where this progression in types is based on a collection providing a larger amount of statistical basis. As regards the other types, worthy of mention is the presence of other tools typical of these phases such as the bladelets with continuous retouch or with notches, of the Montbani type (Fig. 6c: 12-13). Although the flint used is still, for the most part, the same as that used in the preceding notches and denticulates phases, with all the technological constraints implied, laminar knapping was carried out in the same site. On the other hand, the existence of tools (some geometric microliths) made from 


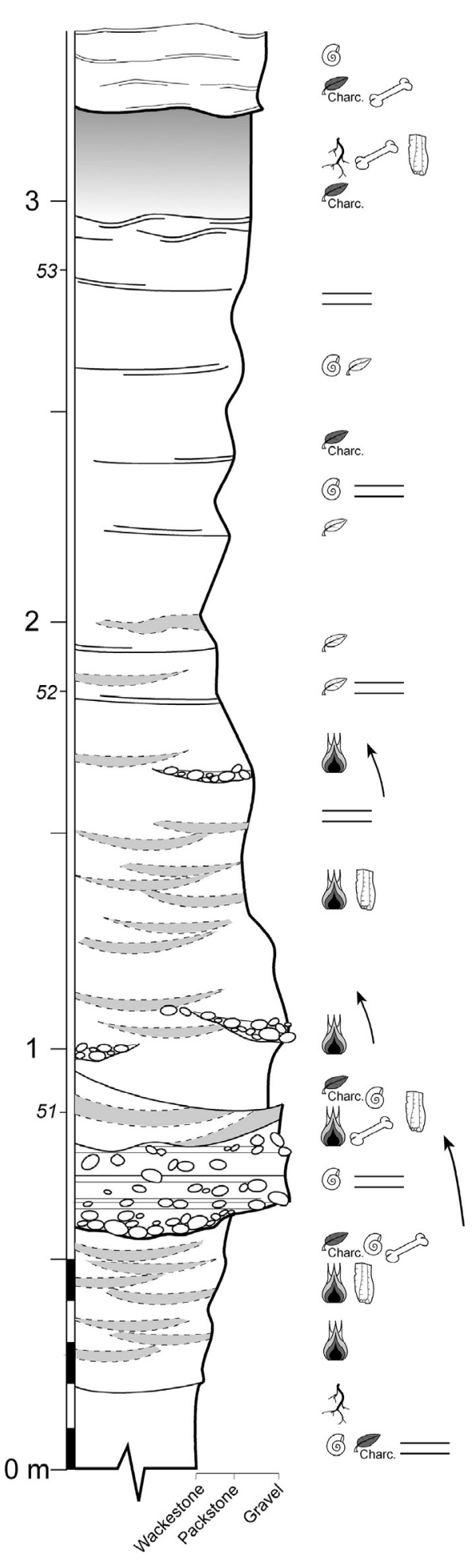

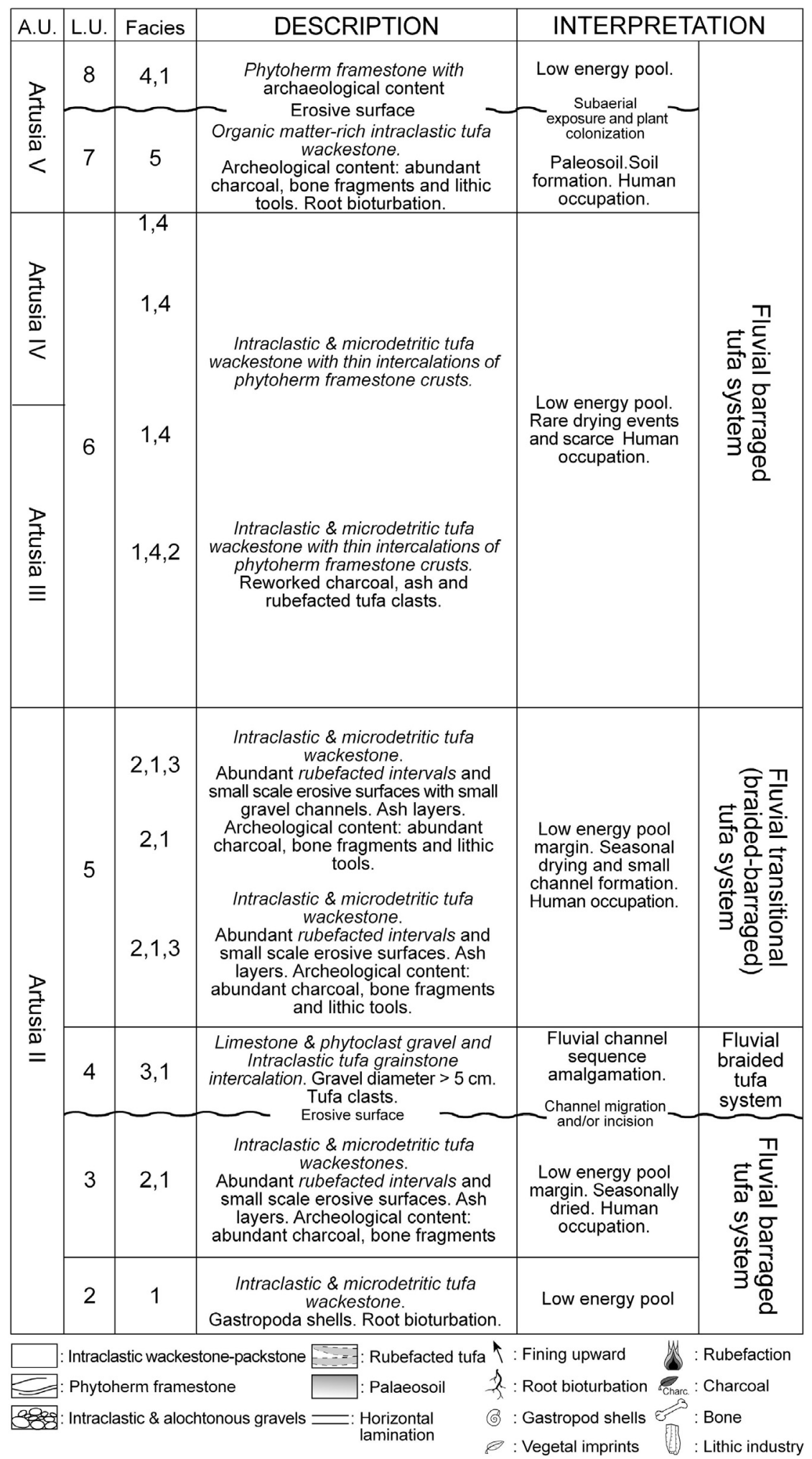

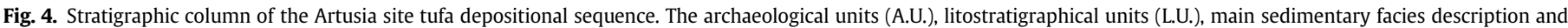
interpretation are represented.

flint that is not locally sourced and more than likely not made at the site itself is recorded for the first time.

The so-called Mesolithic of Notches and Denticulates was recorded conclusively from archaeological point of view for the first time in Navarre at the Artusia site. The sedimentary record provides evidence of more than one phase. This exceptional situation will allow us in the future to ascertain if there are transformations in the industry's components within this broad cultural sequence, such as 

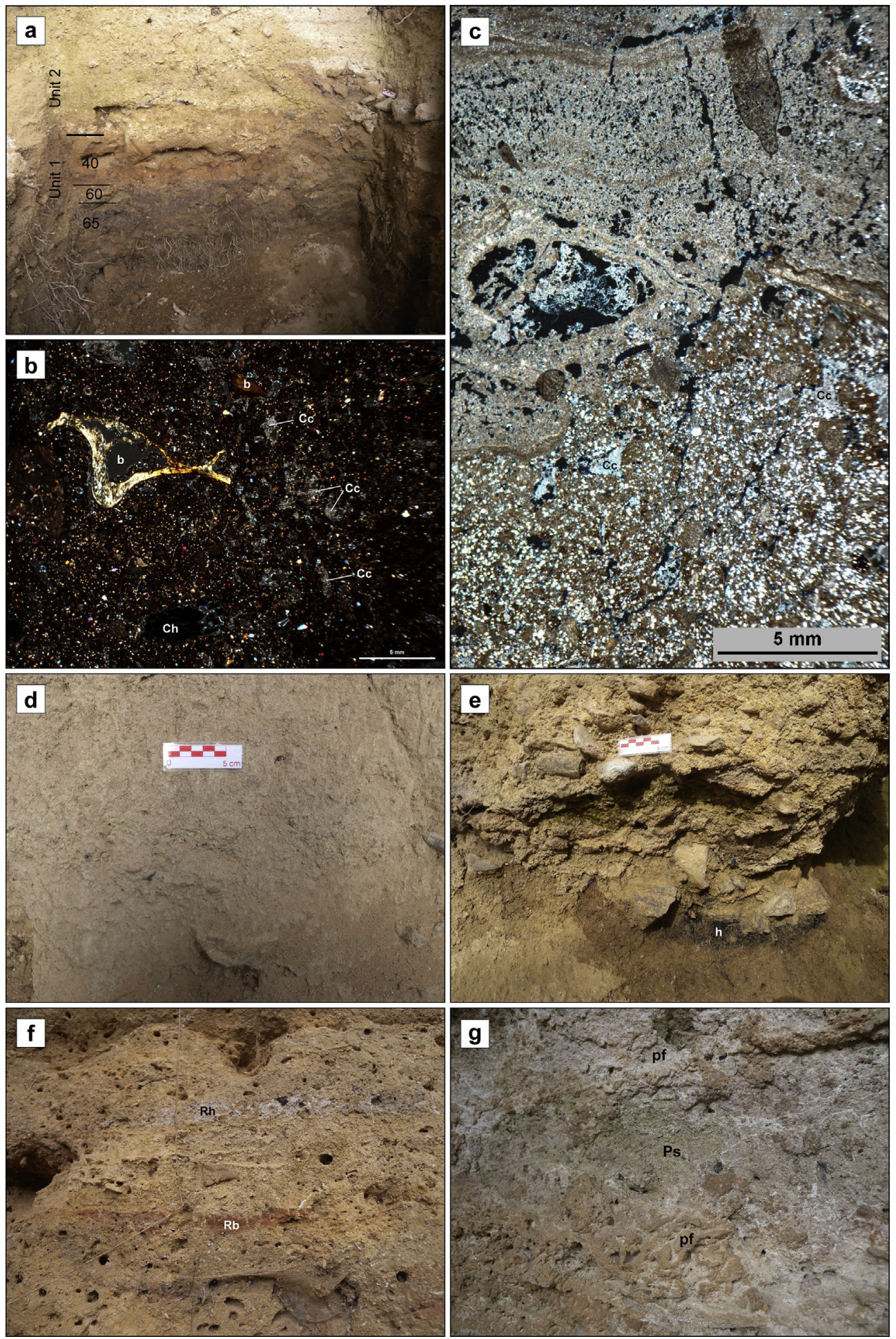

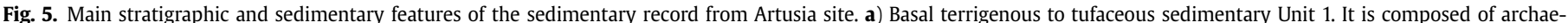

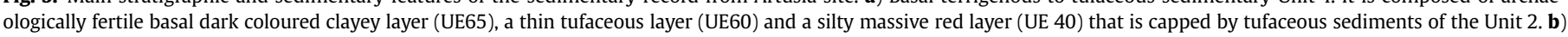

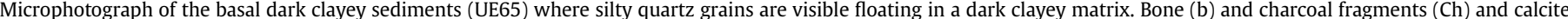

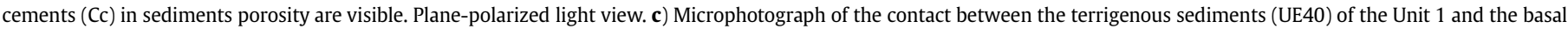

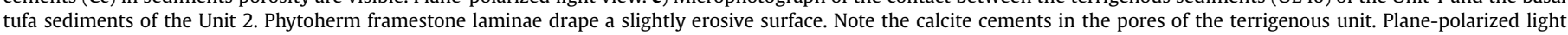

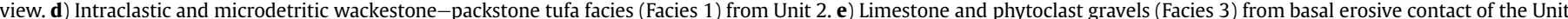

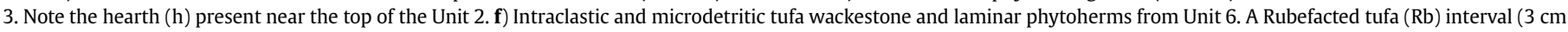

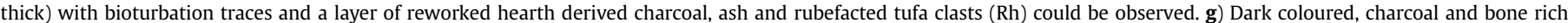

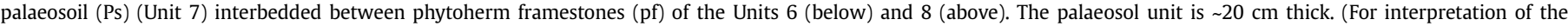
references to colour in this figure legend, the reader is referred to the web version of this article.)

Please cite this article in press as: García-Martínez de Lagrán, I., et al., 8.2 ka BP paleoclimatic event and the Ebro Valley Mesolithic groups: Preliminary data from Artusia rock shelter (Unzué, Navarra, Spain), Quaternary International (2015), http://dx.doi.org/10.1016/ j.quaint.2015.06.050 

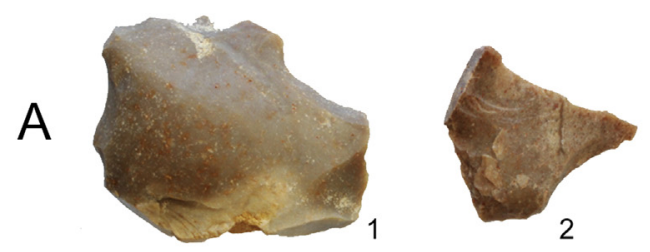

$\mathrm{B}$
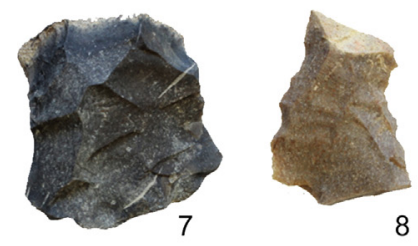

8
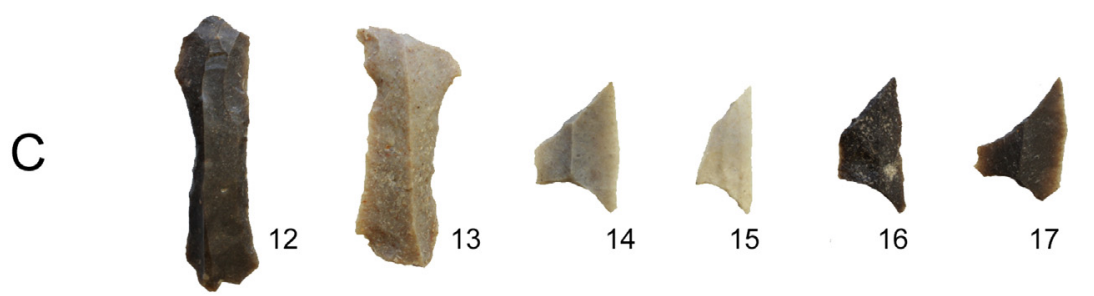

17

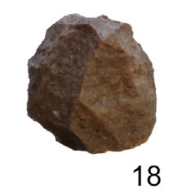

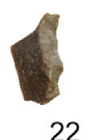

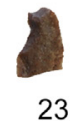

23

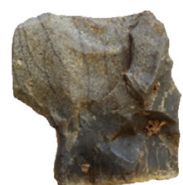

11
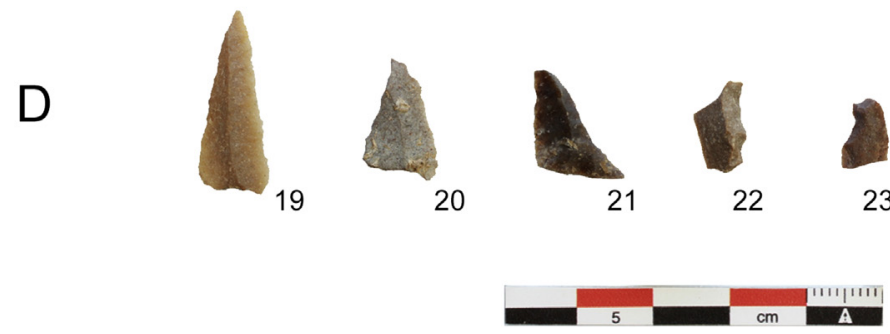

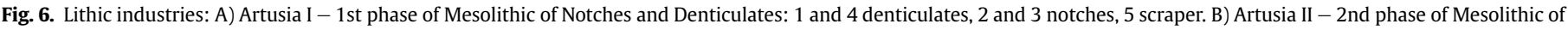

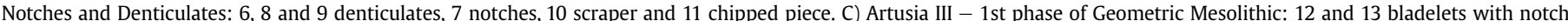

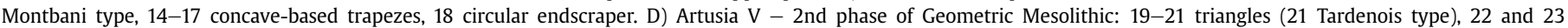
microburins.

those detected in the geometric microliths of the end of the Mesolithic. By this final stage, different ways and "trends" had been set in the lithic industries of these communities throughout the Ebro Basin, and the occupants of Artusia were no different (AldayRuiz, 2006b; Utrilla-Miranda and Montes-Ramírez, 2009).

\subsubsection{Traceology}

The traceological analysis has been carried out on a sample of materials selected from the lithic assemblage on the basis of both morphological and conservation aspects.

The analytical methodology followed a two-step procedure: 1) a first observation of the materials has been realized through stereoscopic microscopy, using a Leica MZ16A, with magnifications between $10 \times$ and $90 \times$, in order to detect all the macroscopic evidences of use (fractures, edge-scarring, roundings, etc.); 2) a second phase at higher magnifications, using the reflected-light microscope Olympus BH2, with observations between $50 \times$ and $400 \times$, in order to detect all the microscopic features (polishes, strias, microfractures, etc.). Microscopic photographs have been taken with a Canon 450D and multifocal images have been mounted with Helicon Focus v. 4.62.

The first aspect to remark is that the Artusia lithic assemblage is extremely altered; even if at a macroscopic observation only few pieces appear patinated or lustred, at a microscopic view almost the entire assemblage shows some type of surface's alteration, mainly due to the soil mechanical weathering, which produces a rounding of all the microtopographic high-points. A group of 40 lithics have been analysed, including retouched implements (geometrics, flakescrapers, denticulates, abrupt retouched tools, etc.) and unretouched blanks: 9 unreoutched blades; 6 unretouched flakes; 9 geometrics; 1 backed tools; 3 flake-scrapers; 9 notched tools; 3 denticulates. As a result of the microscopic analysis, only 9 tools $(22.5 \%)$ of the analysed assemblage present wears of use; the remaining tools correspond to unused elements $(17 ; 42.5 \%)$ or tools that are too altered to be properly analysed and interpreted (14; $35 \%$ ). None of the unretouched implements presented any trace of use. Only one of the unretouched blades was too altered to be analysed.

As regards the retouched tools, of the 9 geometrics analysed, only one of them presents a diagnostic impact fracture: a bending fracture on one of the two tips, which could have been produced by use as a projectile. Of the remaining geometrics, one appears unused, while the other 7 show undiagnostic flexion fractures, which could have been produced either by intentional use or accidentally. The absence of diagnostic wears does not imply that tools have not been used; the experimentation works demonstrate that only a 

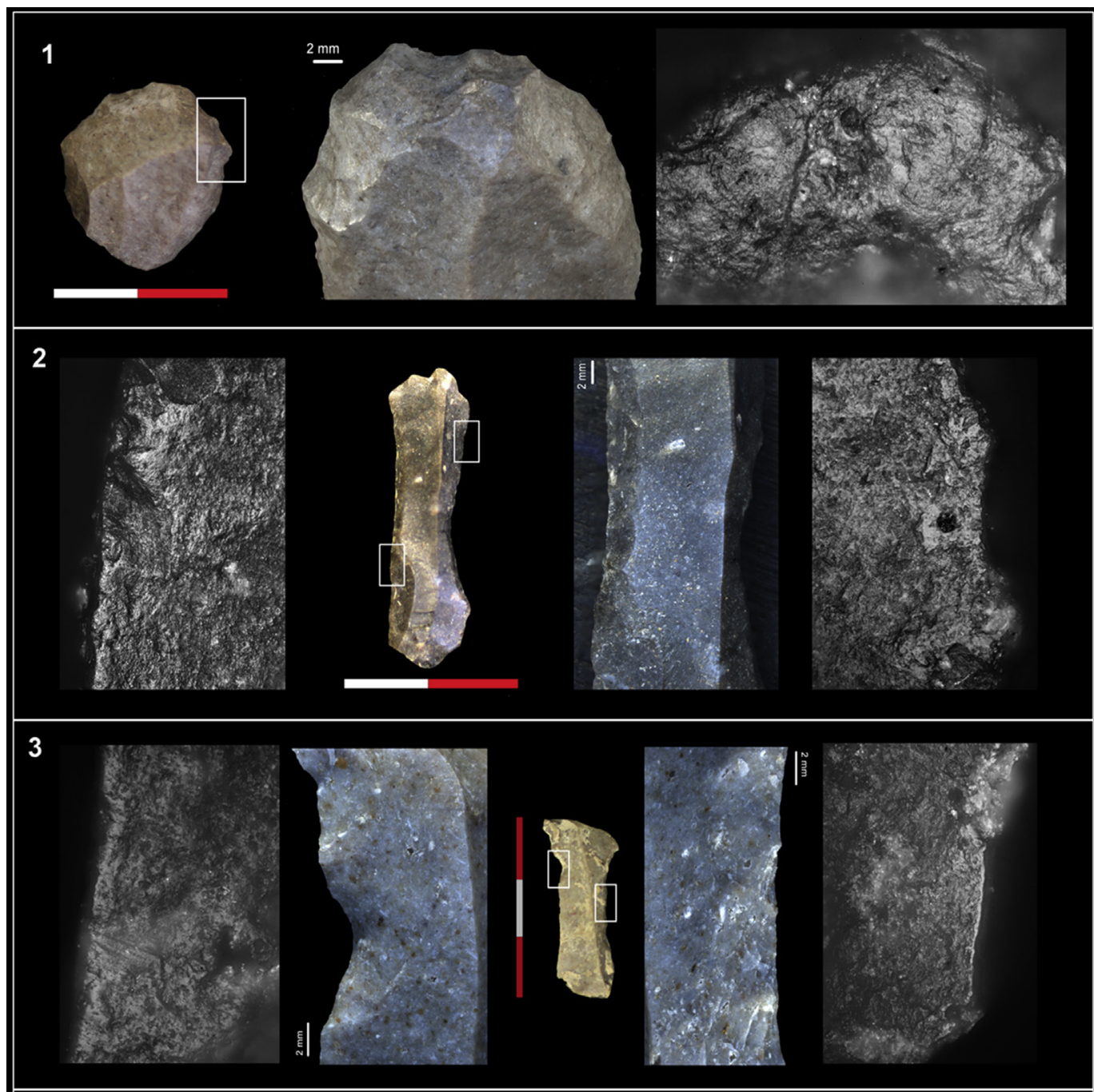

4

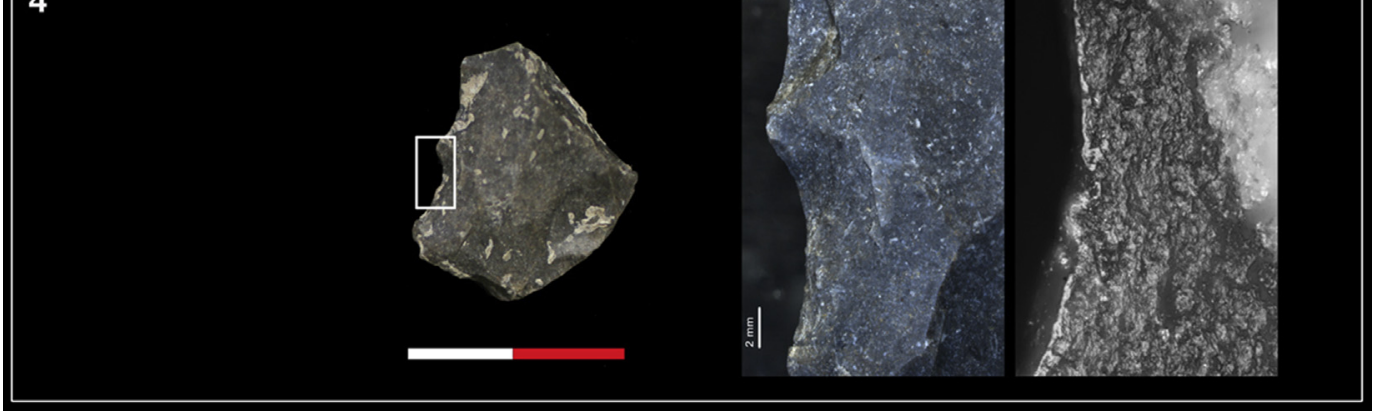

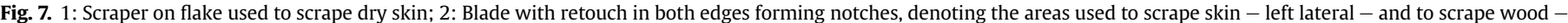

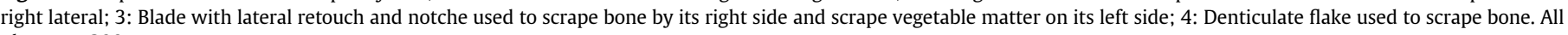
photos at $200 \times$.

reduced percentage of microliths develop impact fractures. Fractures are more frequent when the tip enters in contact with the skeletal parts of the animals (Gibaja-Bao and Palomo-Pérez, 2004).

Of the flake scrapers analysed, two show use-wear traces, while the third one is too altered to be clearly interpreted. Among the used implements, one has been used to scrape hide using the retouched edge as active zone (Fig. 7.1).

Notched tools comprise two blades and seven flakes. Both blades have been intensively used, with various phases of use and reuse. The blade (Fig. 7.2) shows three different active zones, each associated with a different worked material. On the left side, we identified two small areas which have been respectively used for scraping dry hide and for scraping vegetal materials. On the right side, a small portion of the distal edge has been used to scrape a vegetal matter as well, probably wood.

The second blade (Fig. 7.3) has been used on both sides to work different materials: the left side has been used to scrape bone or antler, while the right one to scrape vegetal matter. In any case, both tools were employed for brief tasks, probably crafting activities which required fine and clear work. This type of tool can be considered a versatile crafting tool, which was used and reused in different occasions for different works depending on the needs. 

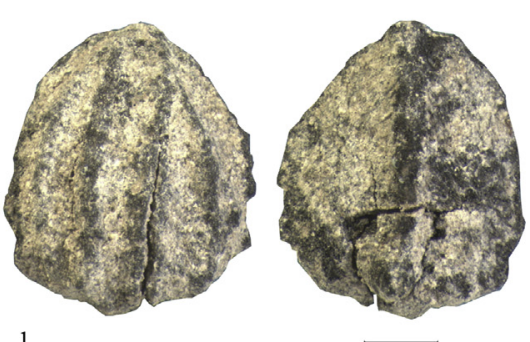

1

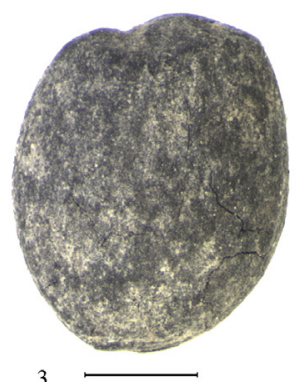

3

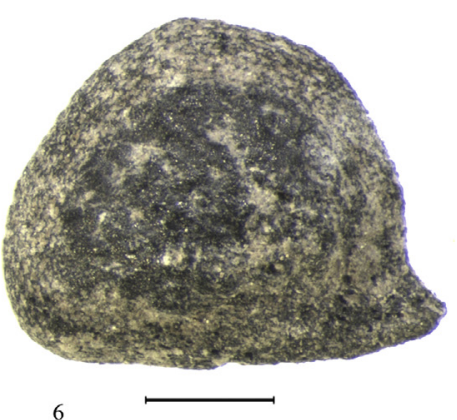

5
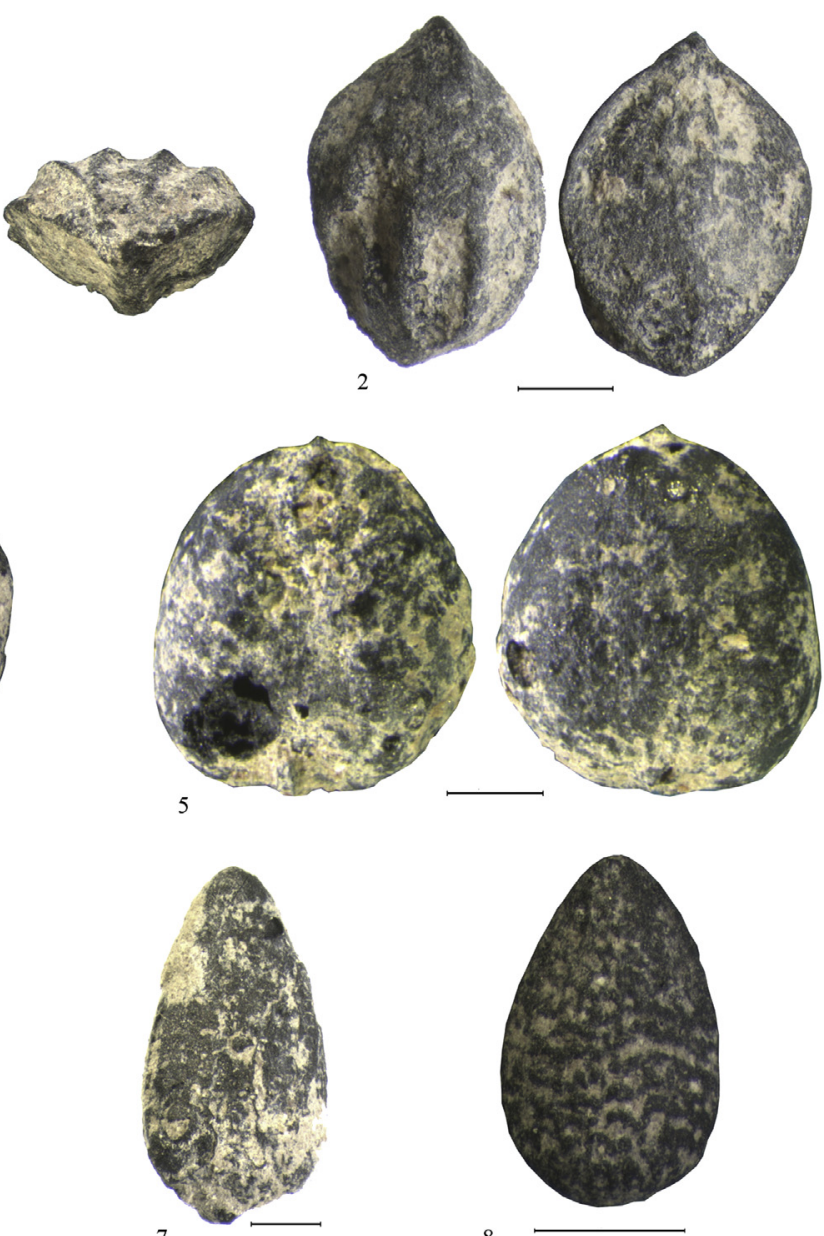

Fig. 8. 1. Arctostaphyllos uva-ursi, 2. Juniperus communis, 3. Pistacia terebinthus, 4. Rubus sp., 5. Viburnum tinus, 6. Ranunculacea, 7. Berberis sp., 8. Sambucus sp.

Only one of the flake scrapers had clear use-wear marks. Two have not been used at all, while the other four are too altered to be interpreted. The used tool (Fig. 7.4) shows a marginal and compact polish on its ventral face, probably produced by the work of a hard material such as bone or hard wood. Finally, the three denticulate flakes have been used for various activities: two of them are used on the retouched edge for scraping respectively bone materials and indeterminable soft matters, while the third one shows wear on the edge opposite to the retouched side and it has been used to cut some type of soft matter.

On the basis of the little information available, it seems that the flaked stone tools were mainly related to hunting activities and the processing of the animal carcasses. Together with the presence of few geometrics (which even if did not show clear traces of impact, can be considered as projectile weapons anyway), we identified tools related to the scraping of hides and the processing of bonewood materials, possibly in relation with resharpening and finishing crafting tasks.

\subsection{Archaeobiology}

Unfortunately, despite the efforts made, the different pollen samples from Artusia were sterile. This is due, in all probability, to the alkaline nature of the carbonate sediments.

\subsubsection{Plant remains}

Despite the limited number of carpological remains found, the information obtained helps to fill in the gaps existing in the Iberian
Peninsula regarding the exploitation of plant resources by hunter-gatherer groups. The plant assemblage identified in Artusia is rather poor in terms of botanical remains. The largest number of samples comes from the first phase of the Geometric Mesolithic while samples recovered from the Mesolithic of Notches and Denticulates and even in the most recent phase, are richer (Table 3).

Table 3

Plant macro-remains. Number of remains (in brackets the frequency).

\begin{tabular}{llll}
\hline & MN\&D & \multicolumn{2}{l}{ GM } \\
\hline $\begin{array}{l}\text { Phase } \\
\text { no of samples }\end{array}$ & 1 & 3 & 5 \\
Fruits & 8 & 17 & 4 \\
$\begin{array}{l}\text { Arctostaphyllos uva-ursi } \\
\text { Berberis sp. }\end{array}$ & $10(3)$ & & $1(1)$ \\
$\begin{array}{l}\text { Corylus avellana } \\
\text { Juniperus communis }\end{array}$ & $1(1)$ & $2(2)$ & $1(1)$ \\
Pistacia terebinthus & $3(2)$ & $1(1)$ & \\
Rubus sp. & $1(1)$ & & $2(1)$ \\
Sambucus sp. & $1(1)$ & & \\
Viburnum tinus & $1(1)$ & $1(1)$ & \\
Fruit fragment & $1(1)$ & & \\
Seeds & & $1(1)$ & \\
Small legume & $1(1)$ & $1(1)$ & \\
Ranunculaceae & $2(2)$ & $1(1)$ & \\
Indet. & & 5 & 4 \\
Cenococcum sclerotia & 20 & 3 & 3 \\
n of remains & 7 & & \\
$\mathrm{n}^{\circ}$ of taxa & &
\end{tabular}


The material has been preserved by charring, and it includes fruits and legumes. The most common taxa is Arctostaphylos uvaursi (bearberry), followed by Pistacia terebinthus, Corylus avellana, Rubus sp. and, to a lesser extent by Juniperus communis, Sambucus sp., Berberis sp., a Ranunculaceae, Actaea spicata which is a wellknown herb, and Viburnum tinus (Fig. 8). The way these species entered the archaeobotanical record probably depends on various causes. Although some species may have been consumed and dispersed by animals (Torroba-Balmori et al., 2013), their preservation by charring suggests some relation of the rock-shelter with human activity. Determining whether they were intentionally collected or incorporated into the archaeobotanical record as part of fuel is, however, rather more complex. Only Juniperus and the legumes appear in both situations, suggesting that at least some of the taxa were intentionally collected.

Edible plants (Arctostaphylos, Pistacia, Rubus, Corylus, Juniperus, Sambucus, Berberis and some legumes) and toxic species such as the Ranunculaceae and Viburnum (Rivera and Obón, 1991) are the largest groups. The constant presence of bearberry may be explained as a result of its growing behaviour in large masses which favours its harvesting. This species, together with others such as Viburnum tinus, points to a humid environment in which stony soils are abundant allowing the development of Pistacia terebinthus while in forested areas, holm oak and common oak developed together with Berberis and junipers (López-González, 2004). The presence of these various environments as suggested by the plant remains points to a systematic exploitation of resources offered by the nearby environment.

The archaeological record of this rock-shelter offers some peculiarities. While in hunter-gatherer sites, acorns and hazelnuts are abundant resources (Zapata-Peña, 2000b; Aura-Tortosa et al., 2005; Antolín-CavaTutusaus et al., 2010; Pérez-Jordà, 2010), in Artusia, acorns are absent. Wood remains of Quercus have been, however, identified amongst the wood charcoal (Table 4). It is likely that the scenario suggested reflects seasonality (Rojo-Guerra et al., 2012) in the occupation of the site. Most remains could have been collected at the end of the summer and during the autumn.

A further distinctiveness is the presence of the bearberry (ArCtostaphylos uva-ursi), unknown in the Iberian archaeobotanical record (Fig. 8.1). This species is, however, well represented in French sites such as la Grotte de l'Abeurador (Vaquer and Ruas,
2009). Bearberry fruits are sour and bitter but they have been traditionally consumed in various forms (dry, boiled and fried), while their leaves have been used for tanning hides (Rivera and Obón, 1991).

Summarizing, the study of Artusia has allowed exploring the use that hunter-gatherer groups made of plant resources. Taphonomic factors clearly determine the presence of plant remains in the archaeobotanical record by favouring the occurrence of faunal remains which have greater visibility and preserve better. Such taphonomic limitations together with the scarce application of systematic recovery of plant remains, has led to an overestimation of the animal resources, which does not correspond to the truth. Artusia represents a new example of the possibilities offered by these types of sites when sampling and recovery are systematically applied.

\subsubsection{Anthracology}

The anthracological remains were recovered as isolated samples $(\mathrm{N}=86)$ during the excavation process and with the flotation machine $(\mathrm{N}=67)$. All were preserved by charring and only remains bigger than $2 \mathrm{~mm}$ were studied. A total of 1113 elements were analysed, of which 866 have been identified, belonging to all the archaeological phases recognised in the Artusia sequence (Table 4). The identified charred woods correspond to a minimum of 10 taxa. The unidentifiable fragments comprise elements with altered anatomy in which diagnostic features were not observable (i.e., green wood, bark, knots).

In addition to scattered charcoals present in the sediment, many hearths were recognised throughout the sequence. Most were formed by accumulations of ash, where no charred wood was identifiable, usually due to their small size, with the exception of SU 100. Thus, as remains from hearths provided limited information on their own, it was decided to sum those elements with dispersed charcoals present in other stratigraphic units which probably derive from cleaning or conditioning the space or from those same hearths and/or reworking during high-water times (Table 4).

The best represented taxa along the entire sequence are Pinus sp. and deciduous Quercus (Quercus petraea, Quercus robur, Quercus pubescens, Quercus faginea, Quercus pyrenaica), both woods of great quality and durability. However, opposite trends in the uptake of these wood resources are clearly observed over time (Fig. 9). During 1 phase of the Mesolithic of Notches and Denticulates (Artusia I) pine wood was the most used. After that

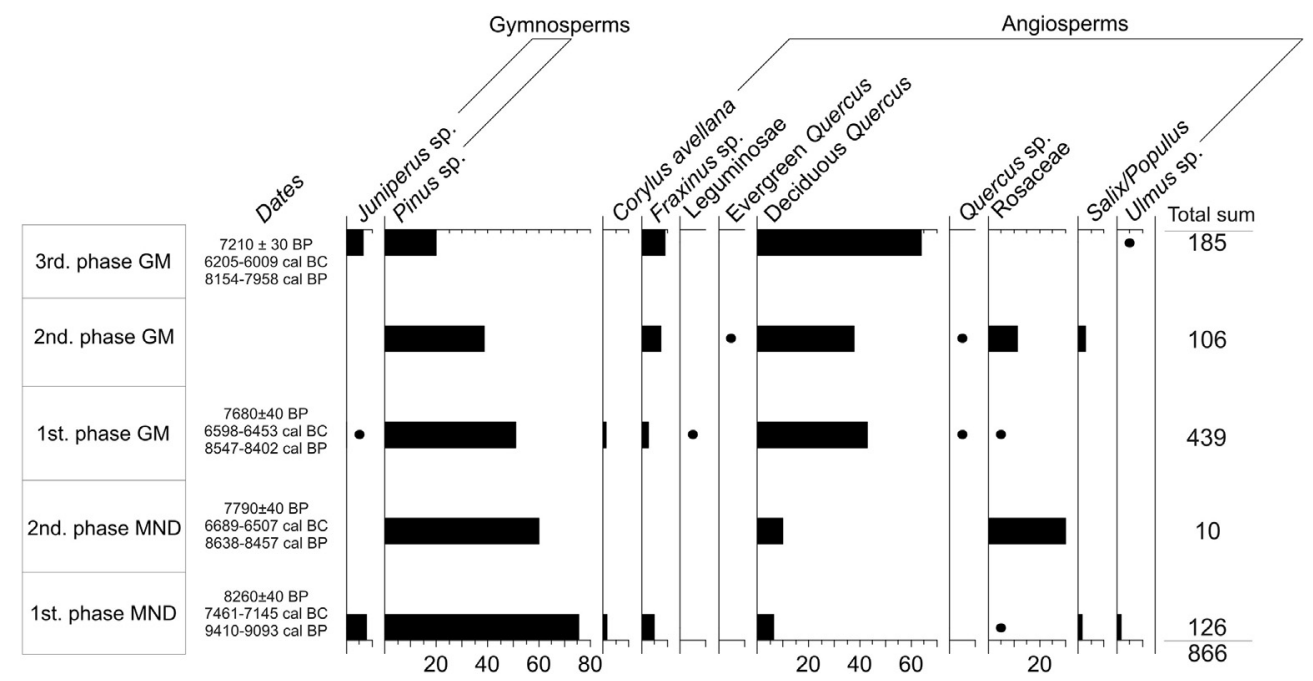

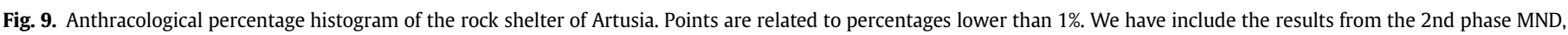
although it has a very low number of charred remains $(n=10)$, because they show the same general trend. 
Table 4

Absolute results of the anthracological study of the Artusia rock shelter divided by stratigraphic unit. * Identified as hearths or ash accumulations.

\begin{tabular}{|c|c|c|c|c|c|c|c|c|c|c|c|c|c|c|c|c|}
\hline & SU & $\begin{array}{l}\text { Corylus } \\
\text { avellana }\end{array}$ & $\begin{array}{l}\text { Fraxinus } \\
\text { sp. }\end{array}$ & $\begin{array}{l}\text { Juniperus } \\
\text { sp. }\end{array}$ & Leguminosae & $\begin{array}{l}\text { Pinus } \\
\text { sp. }\end{array}$ & $E Q$ & $D . Q$ & Quercus sp. & Rosaceae & $\begin{array}{l}\text { Rosaceae } \\
\text { tp. Pomoideae }\end{array}$ & $\begin{array}{l}\text { Rosaceae } \\
\text { tp. Prunus }\end{array}$ & Salix/Populus & Ulmus sp. & Total & No id \\
\hline \multirow[t]{2}{*}{ 3rd. phase GM } & 2 & & 5 & 12 & & 31 & & 35 & & & & & & 1 & 84 & 50 \\
\hline & $100^{*}$ & & 12 & & & 6 & & 83 & & & & & & & 101 & 16 \\
\hline 2nd. phase GM & 3 & & 8 & & & 41 & 1 & 40 & 1 & 5 & 6 & 1 & 3 & & 106 & 20 \\
\hline \multirow[t]{8}{*}{ 1st. phase GM } & 42 & & 5 & & & 27 & & 5 & & & & 1 & & & 38 & 11 \\
\hline & 43 & & 1 & & 2 & 54 & & 72 & & & & & & & 129 & 10 \\
\hline & 110 & & 1 & & & 47 & & 32 & 2 & & & & & & 82 & 12 \\
\hline & 113 & & 2 & & & 16 & & 56 & & 1 & & & & & 75 & 8 \\
\hline & 116 & & 2 & 1 & & 76 & & 23 & & 2 & & & & & 104 & 43 \\
\hline & 5* & & & & & 2 & & 1 & & & & & & & 3 & \\
\hline & $106^{*}$ & & & & & 2 & & & & & & & & & 2 & 1 \\
\hline & $20^{*}$ & 5 & & & & & & & 1 & & & & & & 6 & \\
\hline \multirow[t]{4}{*}{ 2nd. phase MND } & 23 & & & & & & & & & & & & & & & 1 \\
\hline & $25^{*}$ & & & & & 5 & & & & & & & & & 5 & \\
\hline & $30^{*}$ & & & & & 1 & & & & & & & & & 1 & \\
\hline & $49^{*}$ & & & & & & & 1 & & 3 & & & & & 4 & \\
\hline \multirow[t]{4}{*}{ 1st. phase MND } & 65 & 2 & 6 & 10 & & 91 & & 1 & & & & 1 & & & 111 & 75 \\
\hline & 102 & & & & & 1 & & & & & & & & 2 & 3 & \\
\hline & 103 & & & & & 3 & & 7 & & & & & 2 & & 12 & \\
\hline & & 7 & 42 & 23 & 2 & 403 & 1 & 356 & 4 & 11 & 6 & 3 & 5 & 3 & 866 & 247 \\
\hline
\end{tabular}

moment, its importance begins to decrease in parallel with the increase in the values of deciduous Quercus. Thus, in the 1 Geometric Mesolithic phase (Artusia III), their values are very similar. There is a continuous decreasing trend in the uptake of pine while deciduous Quercus increases, being the most widely used wood in the final stages.

Several reasons may be responsible for this pattern. For example, the landscape could have changed because of climate reasons. According to various palaeobotanical records in nearby deposits, pine forests are one of the major forest communities that recolonize the area in the early Holocene (Peñalba, 1992; ZapataPeña and Peña-Chocarro, 2005; Ruiz-Alonso, 2014). Afterwards, they were replaced by other formations adapted to the new environmental characteristics of the Holocene, in a competitive process (Costa-Tenorio et al., 2005). From this perspective, it cannot be excluded that a specialization in sourcing strategies of wood occurred as a result of a change in the preferences of the group who frequented the Artusia rock-shelter. Such evolution in the uptake of wood is not easy to demonstrate because of the absence of other palaeobotanical records, especially palynological, which could determine more reliably the composition of the vegetation of the environment and its possible evolution.

The charred wood located in deposits near Artusia for this chronology show a preference for deciduous wood, in most cases represented by Quercus wood, with small appearances of hazel. This is reflected clearly in deposits of the Bay of Biscay (Zapata-Peña, 2000a, 2012; Ruiz-Alonso, 2014) and the Pyrenees (Zapata-Peña, 2001). Changes in the Ebro Valley are noteworthy. In this area the substitution of pines by deciduous Quercus was observed in anthracological studies from other nearby sites, such as Mendandia (Zapata-Peña and Peña-Chocarro, 2005), Kanpanoste Goikoa (Zapata-Peña, 1998, 2002) and Atxoste (Ruiz-Alonso, 2014). In addition, palynological studies (Iriarte-Chiapusso, 1998, 2006; Sánchez-Goñi, 2004) conclude that the low values of pollen of pines are due to its regional origin, favouring the interpretation of a delivery selection of this wood for certain activities that are unknown.

The rest of the identified taxa: riparian forest communities with ash, Salix/Populus, elms and hazels show low values. In addition, the diagram shows the presence of Rosaceae, juniper, and evergreen Quercus, clearly linked with Mediterranean landscapes (Table 4 and Fig. 9).

\subsubsection{Faunal remains}

The total faunal assemblage recovered from Artusia comprises 3020 remains. $78 \%$ of the sample derives from two horizons associated with the Mesolithic of Notches and Denticulates, Artusia I and II, while the remaining $22 \%$ corresponds to the three horizons, Artusia III, IV and V, related to the Geometric Mesolithic. The largest accumulation of identified specimens was recorded in Artusia I (Table 5). Notwithstanding, the assemblage is dominated by small unidentified bone splinters, usually less than $2 \mathrm{~cm}$ in length. The fact that $60 \%(206 / 348)$ of the identified remains are teeth shows the high fragmentation and strong taphonomic alterations the material went through after deposition. The significant proportion of burnt bones in Artusia II (48\%) and Artusia V (49\%) relates to the presence of hearths, which in turn indicates the anthropogenic origin of most of the assemblage. Butchery marks were visible on four bones: two unidentified splinters (SU 65), a mandible fragment (SU 27) and a large-sized mammal long bone fragment (SU 3). The only remain with carnivore tooth puncture marks was the proximal epiphysis of a large-sized mammal ulna from Artusia II (SU 28-49-66). In sum, the reduced number of identified remains and their poor preservation hinder the recognition of the hunting and subsistence strategies followed by the hunter-gatherer groups that occupied this site, its functionality as well as the season of the year in which they gathered here. However, the variety of identified taxa is similar to that from other contemporary nearby sites with larger samples (Table 5).

Table 5

Artusia rock shelter faunal remains. N: Number of remains, \%D: Frequency of identified taxa; NMI: Minimum Number of Individuals.

\begin{tabular}{|c|c|c|c|c|c|c|c|}
\hline \multirow[t]{3}{*}{ Taxa } & \multicolumn{3}{|l|}{ N\&DM } & \multicolumn{4}{|l|}{ GM } \\
\hline & $\mathrm{HC} 1$ & $\mathrm{HC} 2$ & Total & HC3 & HC4 & HC5 & Total \\
\hline & $\mathrm{N}(\mathrm{NMI})$ & $\mathrm{N}(\mathrm{NMI})$ & $\% \mathrm{D}$ & $\mathrm{N}$ (NMI) & N (NMI) & $\mathrm{N}(\mathrm{NMI})$ & $\% \mathrm{D}$ \\
\hline Horse & $2(1)$ & - & $<1$ & - & $3(1)$ & - & 7 \\
\hline Auroque & $6(1)$ & $2(1)$ & 3 & - & - & $1(1)$ & 2 \\
\hline
\end{tabular}


Table 5 (continued)

\begin{tabular}{|c|c|c|c|c|c|c|c|}
\hline \multirow[t]{3}{*}{ Taxa } & \multicolumn{3}{|l|}{ N\&DM } & \multicolumn{4}{|l|}{ GM } \\
\hline & $\mathrm{HC} 1$ & $\mathrm{HC} 2$ & Total & $\mathrm{HC} 3$ & HC4 & HC5 & Total \\
\hline & $\mathrm{N}(\mathrm{NMI})$ & $\mathrm{N}(\mathrm{NMI})$ & $\% \mathrm{D}$ & $\mathrm{N}(\mathrm{NMI})$ & $\mathrm{N}(\mathrm{NMI})$ & $\mathrm{N}(\mathrm{NMI})$ & $\% \mathrm{D}$ \\
\hline Red deer & $5(1)$ & $4(1)$ & 3 & $1(1)$ & $5(1)$ & $6(1)$ & 28 \\
\hline Roe deer & - & - & - & - & $1(1)$ & $5(1)$ & 14 \\
\hline Goat & $1(1)$ & - & $<1$ & - & - & - & - \\
\hline Chamois & - & - & - & - & $12(1)$ & - & 28 \\
\hline Wild boar & $2(1)$ & $1(1)$ & 1 & - & $1(1)$ & $2(1)$ & 7 \\
\hline Rabbit & $224(8)$ & $44(3)$ & 90 & $4(1)$ & $1(1)$ & - & 12 \\
\hline Canidae & - & $1(1)$ & $<1$ & - & - & - & - \\
\hline Fox & - & - & - & - & - & $1(1)$ & 2 \\
\hline Wild cat & $5(2)$ & - & 2 & - & - & - & - \\
\hline Total identified & $245(15)$ & $52(7)$ & 100 & $5(2)$ & $23(6)$ & $15(5)$ & 100 \\
\hline Total unidentified & 1436 & 518 & & 171 & 105 & 441 & \\
\hline
\end{tabular}

The recorded species of ungulates are: horse (Equus sp.), auroch (Bos primigenius), red deer (Cervus elaphus), roe deer (Capreolus capreolus), goat (Capra pyrenaica), chamois (Rupicapra rupicapra) and wild boar (Sus scrofa). Since the Upper Palaeolithic, subsistence of the human communities from the Iberian Peninsula was based on the hunt of these species. There was no evidence of any domesticates. Two carnivores, fox (Vulpes vulpes) and wild cat (Felis silvestris), and one lagomorphs, rabbit (Oryctolagus cuniculus) complete the faunal spectrum recovered. The latter is the most abundant taxon in the Mesolithic of Notches and Denticulates phase, not only by the number of remains $(\mathrm{N})$ but also by the Minimum Number of Individuals (MNI), while red and roe deer are notable in the small sample recovered from the Mesolithic Geometric phase. In that phase there was a decrease in the faunal spectrum that was particularly noticeable in Artusia III. The significant reduction in the minimum number of individuals recovered ( 22 in the Notches and Denticulates phase $v s 13$ in phase Geometric Mesolithic) is mirrored by the loss of the previous biodiversity (Table 5). Furthermore, the absence of horse and rabbit and the occurrence on site for the first time of roe deer may suggest the exploitation of slightly more forested biotopes in Artusia $\mathrm{V}$ than in the previous horizons, although it might have been a more open forest than in Artusia I when wild cat was present. No sign of skin processing or meat consumption of this taxon was noted (Crezzini et al., 2014). In conclusion, over the whole sequence red deer dominates, but it is evident there was a gradual shift from the exploitation of large to smaller ungulates.

Hunting of young animals are documented in the case of auroch and wild boar, as milk teeth of both species were recovered. The size of two deciduous lower fourth premolars of auroque from Artusia I and II are within the range recorded by Castaños-Ugarte (2006) in the nearby site of Mendandia (Fig. 13). The initial stage of wear of both teeth shows that they belong to individuals between 6 months and one year of age. As the sample is so small, it does not seem suitable to use this data in order to establish the season of the year these animals were hunted. However, their recovery together with that of an auroch third permanent molar and two red deer lower premolars in an advance worn stage in Artusia V suggest hunting strategies might have focused on the most vulnerable age groups: young and old animals.

\section{Discussion and conclusions}

\subsection{Palaeoenvironmental evolution and climatic context}

Carbonate tufa sedimentation occurs from surficial karst water courses flowing from karst aquifers, as is the case in the Artusia River, fed by numerous springs in the Palaeocene limestones of the Alaitz range. Tufa often consists of deposits accumulated in the bottom of fluvial valleys, and formation requires the coincidence of complex processes within hydrological systems (Pentecost, 2005). Fluvial tufas form under humid and relatively warm environmental conditions from aggressive solute free and low terrigenous load water (Pedley, 1990; Pentecost, 2005). They play an important environmental role, as their establishment forms new marsh or pond ecosystems in the valley bottoms. These wetland areas are very sensitive to climatic oscillations (e.g. Andrews, 2006; Viles et al., 2007; González-Amuchastegi and Serrano, 2015; Ibarra et al., 2015), being extremely fragile depositional environments that respond rapidly to changes in both natural and anthropicallyinduced environmental dynamics. The calcareous tufas are therefore key elements in reconstructing and understanding the palaeoenvironmental evolution and its climatic controls and/or human impacts (Dabkowski, 2014). In Artusia, the paleoenvironmental value is joined by the archaeological, with a Mesolithic archaeological record with an exceptional temporal resolution due to the high sedimentation rates of the tufa system.

Considering the sedimentological features and depositional processes inferred from the different lithostratigraphic units of the Artusia site, the following evolutionary sequence could be deduced: the establishment, at ca. 7500 cal BC-9000 cal BP, and aggradation of a fluvial barraged tufa system (Units 2-7) over previous siliciclastic floodplain sediments (Unit 1) (7450-7150 cal BC 9400-9100 cal BP). During the deposition of the tufa system a progressive rise of the water table resulting in pooled fluvial areas, with a marked seasonality occurred. The waterflow seasonality controlled the periodical subaerial exposure of pool-shores during low-water seasons (Unit 2 and 5). A general tendency to more humid and higher water levels that progressively reduced the time and the extent of emerged (archaeological occupation) areas is observed (Unit 6). However, this evolution is interrupted by two arid events, lowering the water table, and leading to a lower sedimentary rate and even the incision and erosion of the underlying tufa deposits (Unit 4) (ca. $6550 \mathrm{cal} \mathrm{BC}-8500 \mathrm{cal} \mathrm{BP}$ ) and the formation of paleosoils (Unit 7) ( $c a .6250 \mathrm{cal} \mathrm{BC}-8200 \mathrm{cal} \mathrm{BP}$ ). The archaeological area corresponds to the shore of a pooled area that was situated under a limestone shelter, and was occupied by seasonal settlements of Mesolithic human groups in summer times. Finally, after Unit 8 sedimentation, a progressive lowering in the water level during Middle and Late Holocene caused the incision and erosion of nearly all previous tufa deposits and the formation of the tufa terrace where Artusia is located.

In the Mediterranean-transitional low mountain environment of the North Iberian Peninsula where the Artusia site is located, there are numerous tufa buildups in bottom valleys and slopes (Vázquez-Urbez, 2008; González-Amuchastegui and Serrano, 2013, 2015; González-Martín and González-Amuchastegi, 2014). 
Unfortunately, scarce data exist on climatic evolution in the mountains and valleys of the Upper Ebro. Nevertheless, recent synthesis works of different studies of marine to continental records from, both the Cantabrian Mountains and Ebro Valley make it possible to suggest a general approximation of climatic evolution in the study area (González-Sampériz et al., 2008, 2009; Sancho et al., 2008; González-Amuchastegui and Serrano, 2015).

The archaeosedimentary record of Artusia site encompasses the Early Holocene landscape evolutionary phases described in González-Amuchastegui and Serrano (2015) based on tufa system, vegetation, and human impact evolution. In their Phase 2, from Late Glacial and during the Preboreal, an Atlantic mixed forest of Pinus and Betula landscape with wet, warm conditions developed. This was the context for the establishment of the Artusia tufa system (Unit 2), the warmer and more humid conditions increased the karst water availability for the tufa formation, replacing the terrigenous siliciclastic fluvial sedimentation (Unit 1).

From 8300 cal BP (6350 cal BC), organic levels attributed either to edaphic horizons, erosion and accumulation in the valleys or to fires are recorded in the tufas lithostratigraphic records, accompanied with a generalized sharp fall in arboreal percentages together with the expansion of grasses (González-Amuchastegui and Serrano, 2015, their Phase 3). Both in the Cantabrian margin and the central Ebro Basin, a phase of marked dryness and cooling has been reported (García-Amorena et al., 2008; Sancho et al., 2008; González-Sampériz et al., 2009; Muñoz-Sobrino et al., 2009; Moreno-Caballud et al., 2011; González-Amuchastegui and Serrano, 2015). This phase is interpreted as the landscape response to an abrupt climatic Boreal event that brought on an erosional crisis, organic accumulations, open forests of conifers and deciduous trees and a decrease in water availability that affected the vegetation resources and led to subsequent animal migration, degrading the basis for the hunter-gatherer type of life (Sancho et al., 2008; González-Samperiz et al., 2009; GonzálezAmuchástegui and Serrano, 2015).

The Artusia site comprises an outstanding archaeosedimentary record for this abrupt climatic event. The high sedimentary rate of the tufa system allowed an extended record of the 6450 to $6150 \mathrm{cal}$
BC -8400 to 8100 cal BP interval comprising $2.5 \mathrm{~m}$ of sediments and the Mesolithic archaeological record. The $8.2 \mathrm{ka}$ BP event is marked by an organic horizon comprising a paleosol (Unit 7) interpreted as an abrupt, dry and brief change on the hydrological dynamics of the tufa system, changing from aggradation to incision and thus creating vegetated emerged areas where soil formation occurred. Geometric Mesolithic human groups occupied this palaeosol. Moreover, in the Artusia site sedimentary record, a previous similar dryness event is detected at ca. $8.5 \mathrm{ka}$ (Unit 4) (Fig. 4). This aridity event was controlled by similar environmental changes but it was less intense. An abrupt fall in water availability implied the incision of the tufa system but not to the same intensity as the later event. Afterwards, the system progressively recovered its humidity (Units 3 and 4) until the onset of the $8.2 \mathrm{ka}$ BP event.

Therefore, the Artusia site record includes an organic horizon and a vegetation and hydrological response that coincides chronologically with the $8.2 \mathrm{ka}$ BP event, an abrupt, cold, dry and brief change in time recorded on a global scale (Alley and Agústsdóttir, 2005; Kobashi et al., 2007). Moreover, the high-resolution of the Artusia record indicate that this arid event was preceded by another short-duration, ca. $100 \mathrm{y}$, arid event at ca. 6550 cal $\mathrm{BC}-8500$ cal BP that marks the transition between major Mesolithic phases. It is proposed that the Mesolithic techno-typological transition, at least in Artusia, roughly coincided with the $8.2 \mathrm{ka}$ major arid climatic event. In greater detail, as it is possible to observe in Artusia, it coincided with a previous arid event at ca. 6550-6450 cal BC - 8500-8400 cal BP (Fig. 10).

\subsection{Artusia in the regional Mesolithic framework}

The Artusia rock shelter fits perfectly into the general sequence of the Mesolithic in the Ebro Basin, and shares several characteristics present in other contexts with the same chronology (AldayRuiz, 2006a,b,c; Utrilla-Miranda and Montes-Ramírez, 2009; Utrilla-Miranda, and Mazo-Pérez, 2014):

The type of settlement and its location: a constant aspect of the period is the occupation of small rock shelters used for specialised activities, mainly hunting. These settlements are located in

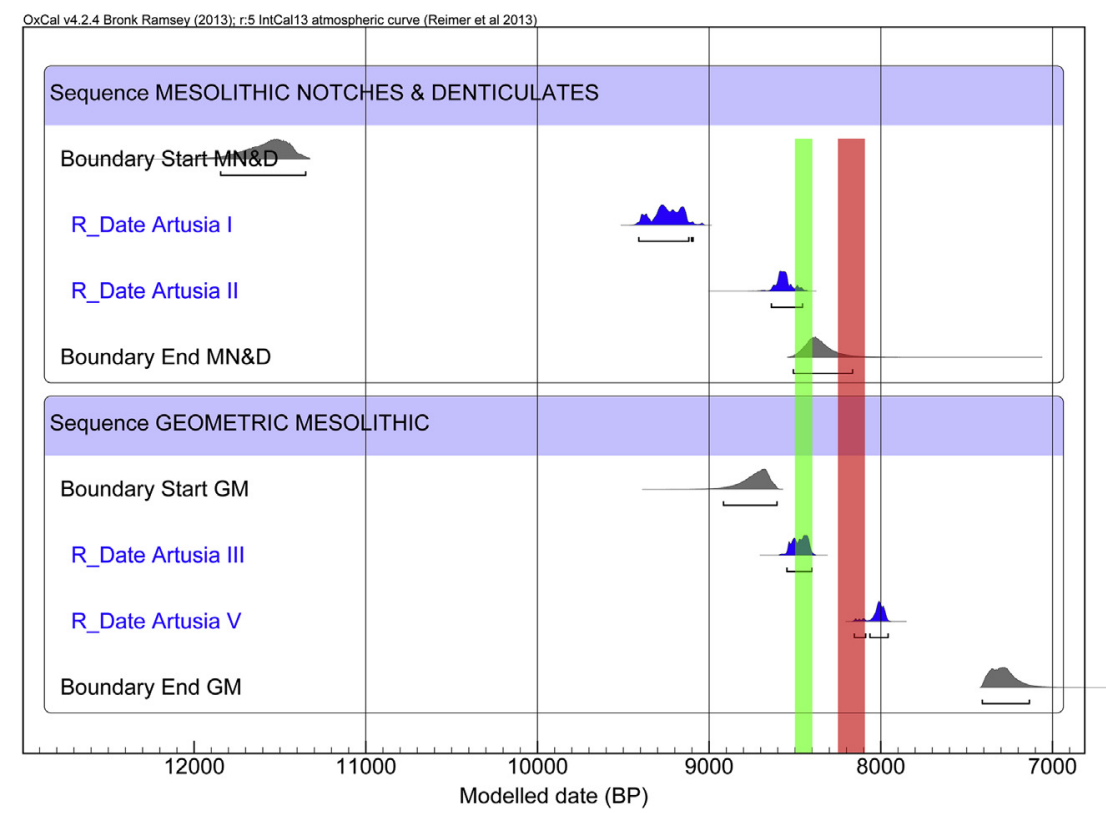

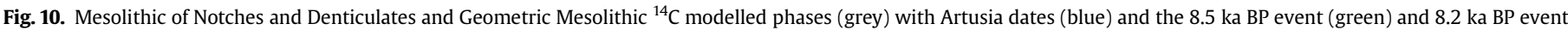
(red). The dates are listed in Table 1. (For interpretation of the references to colour in this figure legend, the reader is referred to the web version of this article.) 
strategic spots (mountain passes, at the entrance or at the end of a valley, in narrow passes) near differentiated biotopes providing access to a large variety of animal and vegetable resources. Artusia is no exception, as it is located at the foot of the Alaitz mountain range and Peña de Unzué and close to the flatter lands of the Pamplona Basin and the Ebro Valley, and near a constant water source (Fig. 1).

These sites were occupied on a seasonal basis and Mesolithic groups developed a wide range of activities, with the hunting of ungulates being of particular importance (Castaños-Ugarte, 2006; Alday-Ruiz, 2006b; Utrilla-Miranda and Montes-Ramírez, 2009) (Table 5). The paleobotanical remains and certain characteristics of the faunistic remains in Artusia have an impact on this question of seasonality and the hunting of ungulates, mainly in summer and autumn.

The Mesolithic phases are determined by the evolution of the lithic industry. In the case of Artusia, we have found no contexts belonging to the Laminar Mesolithic (the earliest stage of the regional Mesolithic) but we have found some from the Mesolithic of Notches and Denticulates and the Geometric Mesolithic. Moreover, Artusia's limited, though representative, lithic collection affords us a clear view of different moments in these phases. Apart from these data, traceology has helped to explore the site's nature which is closely related to hunting (also seen in other contexts), although evidence is scarce (projectiles, hide treatment, etc.) due to the poorly preserved sample.

As can be appreciated in Figs. 10 and 11, the dates place Artusia within the framework of the regional Mesolithic and certain climate events. Although, quantitatively speaking, the archaeological remains in Artusia are not very significant, the paleoenvironmental data obtained in conjunction with radiocarbon dating put this Navarre site at the centre of the debate on the climatic and (pre)historical evolution of the Mesolithic in the Ebro Basin.

\subsection{Climate events and the Mesolithic in the Ebro Basin: causes for explaining the archaeological record}

Two different, though chronologically close, climate events were identified in the Artusia's sedimentary record: the $8.5 \mathrm{ka}$ BP event (ca. 6550-6450 cal BC $-8500-8400$ cal BP) and the $8.2 \mathrm{ka} \mathrm{BP}$ climate event (ca.6300-6140 cal BC-8250-8090 cal BP) (Fig. 10). The precision of these data obtained in the Artusia rock shelter for the first time allows us to relate these environmental changes to evolutionary hypotheses regarding the Mesolithic in the Ebro Basin. We are aware that these are preliminary hypotheses and that certain aspects of our analysis will need to be explored from new perspectives with a larger amount of data. For instance, in the future, the evolution of faunal remains will need to take into account questions related to the different levels of conservation of remains, the minimum number of individuals or the analysis of the greater or lesser occupation intensity on the basis of how the hunted prey is processed.

\subsubsection{Change from the Mesolithic of Notches and Denticulates to the Geometric Mesolithic?}

This is one of the questions that has intrigued researchers on the Mesolithic in recent years. Fig. 11 shows how the identified dry event occurs in the transition period between the Notches and Denticulates phase and the Geometric phase. The start of the Geometric Mesolithic is delayed with respect to this event. This is indicated by the oldest radiocarbon dates at the start of this period and their considerable calibrated gaps, specifically for Ángel $18 \mathrm{c}$ and Aizpea I (Fig. 11 and Table 1). It is logical to think that future radiocarbon dating will provide more precise model dates and phases which, according to available data, is very likely to point to
6550 cal BC -8500 cal BP. Moreover, in the Artusia III phase (6598-6453 cal BC - 8547-8402 cal BP), there is a certain faunal impoverishment, which could be caused by this event (Table 5).

Depending on their chronology (Fig. 11), pollen data from other sites likewise suggest the existence of this $8.5 \mathrm{ka}$ BP event at a regional level. In Mendandia, from level III-inferior, a change is appreciable in the dynamics of the plant environment with a downward trend in tree cover. These changes in Mendandia's vegetation environment in a succession of samples that are not far apart in time (the time frame covered would be approximately 1500 years), are strikingly abrupt (Iriarte-Chiapusso, 2006). These deforestation processes are likewise detected in the site of Los Baños where the regression of the tree mass in favour of herbaceous plants can be appreciated in this time frame (Utrilla-Miranda and Rodanés, 2004).

Consequently, Mesolithic groups were possibly faced with a scarcity of prey in an increasingly open environment (aridity and deforestation), which required forms of hunting to be adapted to suit this new environment: the projectile points made using geometric microliths. Therefore, this technological change, which is not exactly abrupt (Cava-Almuzara, 2004a,b), could be explained by adaptation to a new environment determined by this $8.5 \mathrm{ka} \mathrm{BP}$ environmental change and the subsequent $8.2 \mathrm{ka}$ arid event.

\subsubsection{The $8.2 \mathrm{ka}$ BP event: we still are looking at the sky, while walking on the earth ...}

Abundant bibliography has been created on this climate event in recent years. It has likewise been related to historical processes in the continent as a whole, such as the Neolithisation of Europe (for example: Berger and Guilaine, 2009), and also in the Iberian Peninsula, for example, in Valencia, where López-Sáez et al. (2008: 71) recorded the incidence of this event in the absence of stratigraphies during the Mesolithic-Neolithic transition, as seen, for example, in the La Falguera rock shelter.

With regard to the Ebro Basin, we would mention works by González-Sampériz et al. (2009) and Utrilla-Miranda et al. (2009), both of which focus on the consequences of this climatic phenomenon for the Neolithisation of the Aragon region, and, by extension, of the Ebro Basin. According to these authors, the weak environmental balance of lower Aragon led to the area being abandoned in the period from 6250 to $5750 \mathrm{cal} \mathrm{BC}-8200$ to 7700 cal BP and re-occupied between the following 500 and 1000 years, coinciding with the $C$ phase of the regional Mesolithic to Neolithic transition.

Artusia's record reveals that the arid conditions and deforestation are more extreme during this climate event (8.2 ka BP). In other nearby contexts, the possible consequences of the $8.2 \mathrm{ka} \mathrm{BP}$ event can be appreciated in the pollen record. Apart from the data on peat and natural deposits (Pérez-Díaz, 2012), in Kanpanoste Goikoa a drop in tree cover is evident around 6450-6000 cal BC - 8400-7950 cal BP (Iriarte-Chiapusso, 1998), although in this case, we must be cautious because of the stratigraphic circumstances of the sequence. Similarly, at level 4 in Botiquería, a moment of climate transition is evident in the fact that the vegetation ecosystems tend to become more open (López-García et al., 1991) (Fig. 11)

We are therefore dealing with a series of data that demonstrate the more than probable incidence of the $8.2 \mathrm{ka}$ BP climate event and its arid conditions, seasonality, cold and deforestation during the Mesolithic in the Ebro Basin. This incidence is clear if we analyse the evolution of the hunter-gatherer groups in a global fashion through this phase.

During the Laminar Mesolithic, Mesolithic of Notches and Denticulates and the initial part of the Geometric Mesolithic, up to approximately $8050-7950$ cal BP $-6100-6000$ cal BC, there is a 


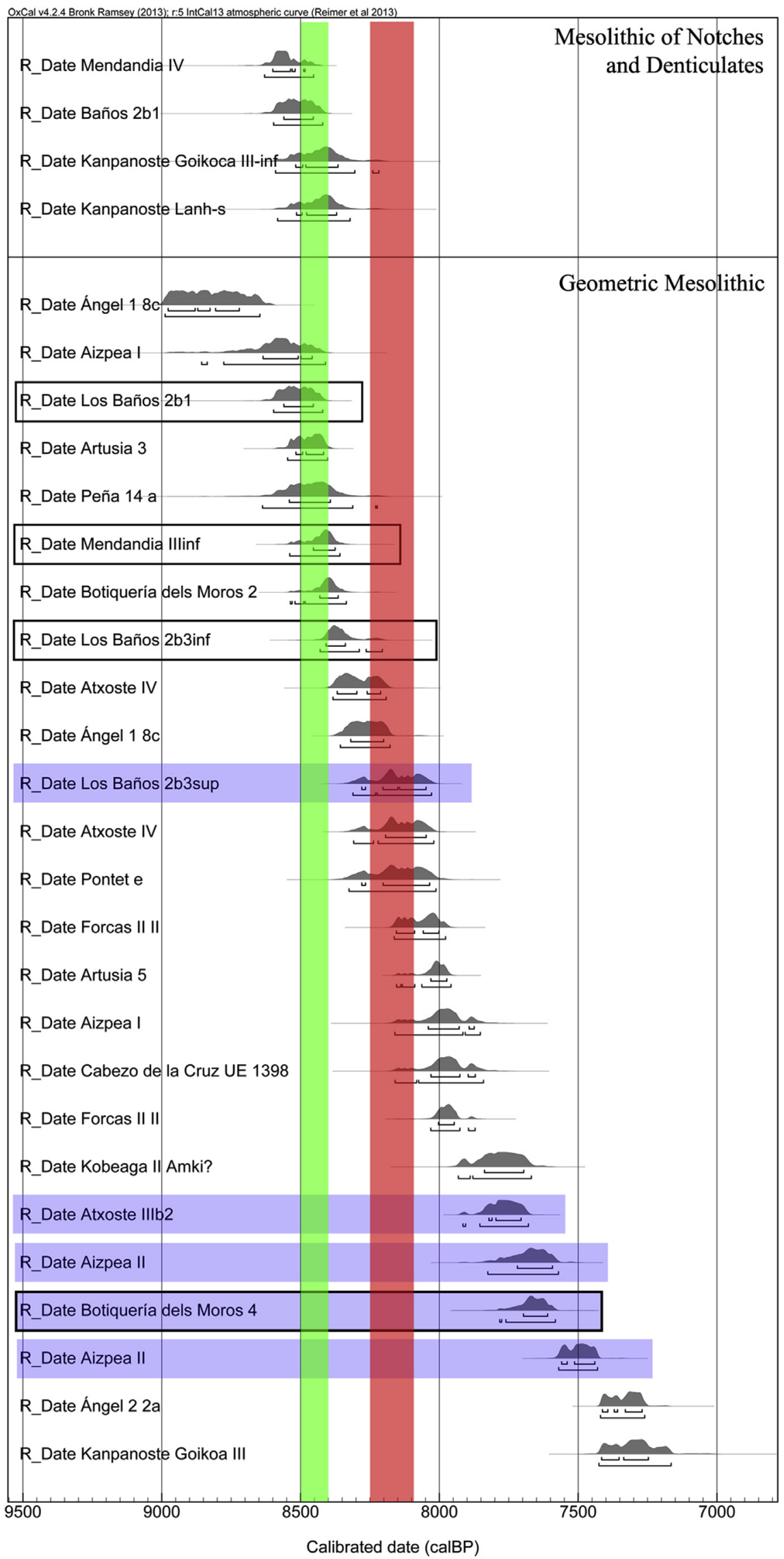

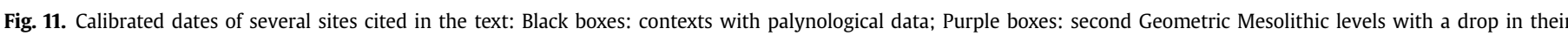

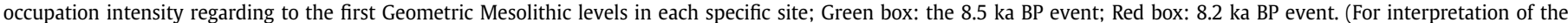
references to colour in this figure legend, the reader is referred to the web version of this article.)

Please cite this article in press as: García-Martínez de Lagrán, I., et al., 8.2 ka BP paleoclimatic event and the Ebro Valley Mesolithic groups: Preliminary data from Artusia rock shelter (Unzué, Navarra, Spain), Quaternary International (2015), http://dx.doi.org/10.1016/ 


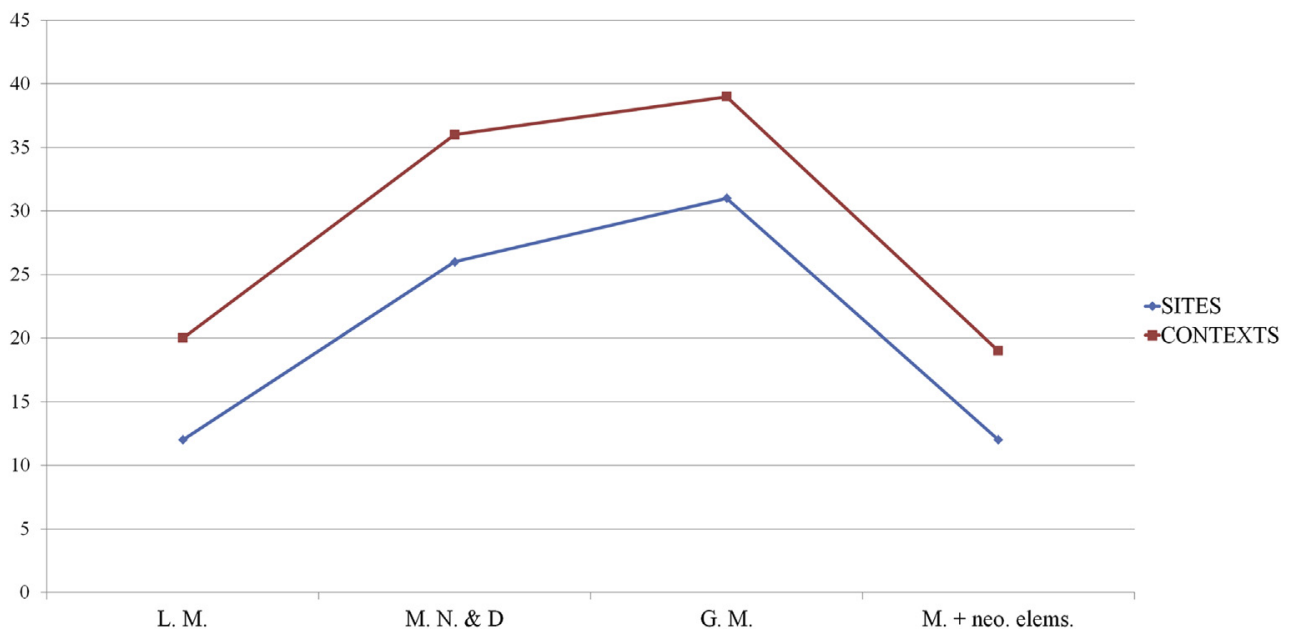

Fig. 12. Archaeological contexts and site evolution during the Mesolithic in the Ebro Basin.

progressive intensification and exploitation of the territory in the Ebro Basin. Subsequently, there is a gradual decrease in the use of these sites and they practically disappear with the onset of the Neolithic.

This affirmation is made on the basis of the following arguments:
1) The progressive increase in the number of sites and contexts throughout this period (Barandiarán-Maestu and CavaAlmuzara, 2001: 521; Alday-Ruiz, 2002: 87; Cava-Almuzara, 2004a,b: 22-23; García-Martínez de Lagrán, 2008). As shown in Fig. 12, this increase is very clear in the early stages up to the Geometric Mesolithic.

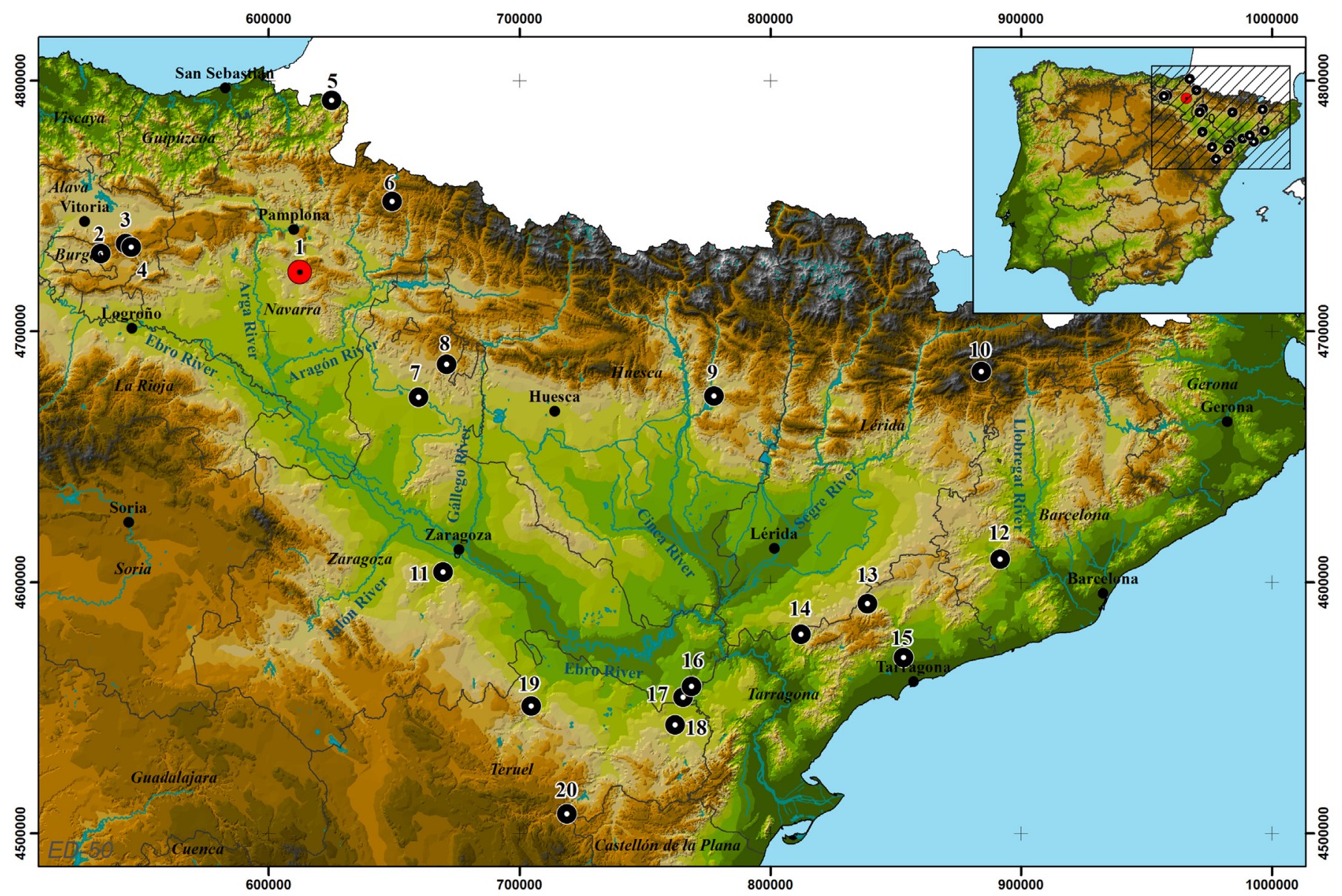

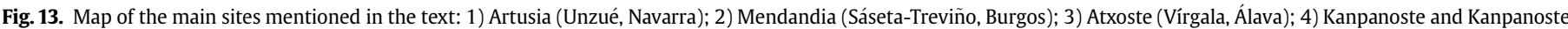

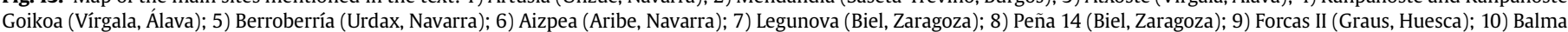

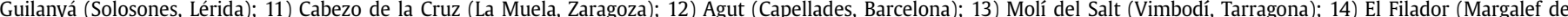

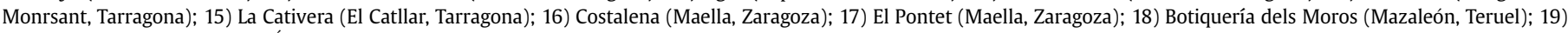
Los Baños (Ariño, Teruel); 20) Ángel 1 and 2 (Ladruñán, Teruel).

Please cite this article in press as: García-Martínez de Lagrán, I., et al., 8.2 ka BP paleoclimatic event and the Ebro Valley Mesolithic groups: Preliminary data from Artusia rock shelter (Unzué, Navarra, Spain), Quaternary International (2015), http://dx.doi.org/10.1016/ j.quaint.2015.06.050 
Table 6

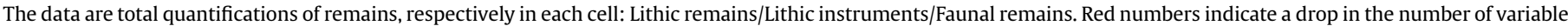

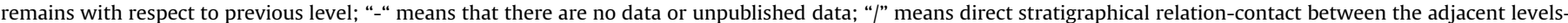

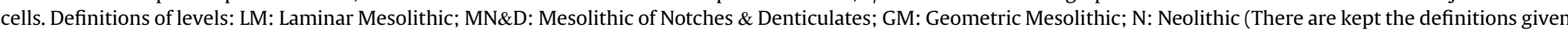

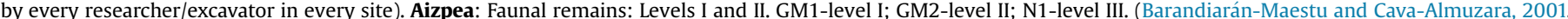

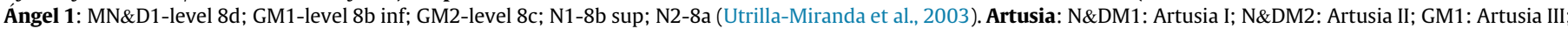

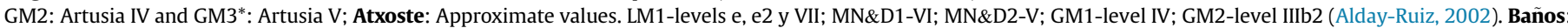

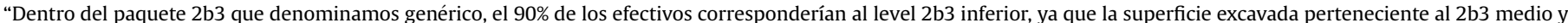

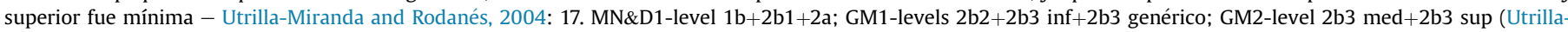

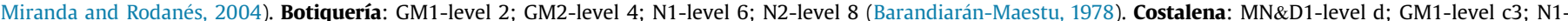

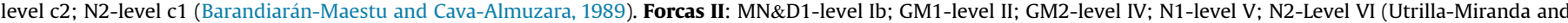

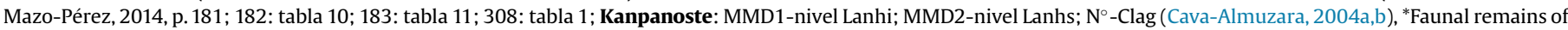

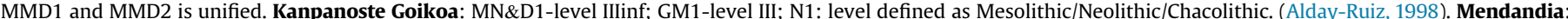

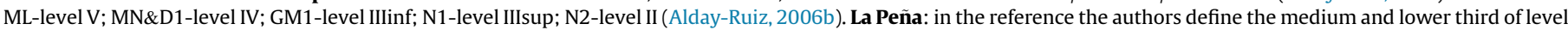

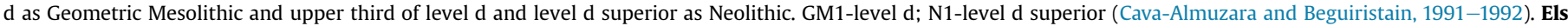
Secans: GM1-level IIb; N1-level IIa Utrilla-Miranda and Montes-Ramírez, 2009

\begin{tabular}{|c|c|c|c|c|c|c|c|}
\hline $\begin{array}{l}\text { Total number } \\
\text { of: Lithic } \\
\text { remains/Lithi } \\
\text { c } \\
\text { instruments/F } \\
\text { aunal remains }\end{array}$ & LM1 & MN\&D1 & MN\&D2 & GM1 & GM2 & N1 & $\mathrm{N} 2$ \\
\hline Aizpea* & & & & $3098 / 155 /-$ & $\begin{array}{c}4003 / 186 / \\
857\end{array}$ & $\begin{array}{c}2093 / 104 / 7 \\
5\end{array}$ & \\
\hline Ángel 1* & & $-/ 87 /-$ & 1 & $-/ 14 /-$ & $-/ 151 /-$ & $-/ 78 /-$ & $-/ 76 /-$ \\
\hline Artusia* & & $261 / 15 / 1681$ & $\begin{array}{c}\mathbf{5 8 2} / \mathbf{1 6} / 57 \\
0\end{array}$ & 209/16/176 & $\begin{array}{c}\text { GM2: } \\
\text { 0/0/128 } \\
\text { GM3*: } \\
\text { 161/15/44 } \\
\mathbf{6}\end{array}$ & & \\
\hline Atxoste* & $\begin{array}{c}1600 / 77 \\
/-\end{array}$ & $3600 / 60 /-$ & $3700 / 95 /-$ & $4700 / 300 /-$ & 2600/200/- & & \\
\hline Baños & & $1552 / 53 / 222$ & / & $\begin{array}{c}1237 / 57 / 53 \\
\mathbf{6}\end{array}$ & $\begin{array}{c}359 / 22 / 12 \\
6\end{array}$ & $*$ & \\
\hline Botiquería & & & & $\begin{array}{c}5831 / 356 / 7 \\
4\end{array}$ & $\begin{array}{c}564 / 141 / 8 \\
\mathbf{9}\end{array}$ & $\begin{array}{c}1486 / 104 / \mathbf{1} \\
\mathbf{2 9}\end{array}$ & $\begin{array}{c}360 / 23 \\
/ 20\end{array}$ \\
\hline Costalena & & $837 / 72 / 141$ & / & $\begin{array}{c}8394 / 539 / 2 \\
277\end{array}$ & l & $\begin{array}{c}3244 / 275 / 5 \\
91\end{array}$ & $\begin{array}{c}590 / 34 \\
/ 70\end{array}$ \\
\hline Forcas II & & & & $\begin{array}{c}788 / 66 / 233 \\
4\end{array}$ & $\begin{array}{c}\mathbf{1 3 5 5} / \mathbf{1 0 2} / \\
1280\end{array}$ & $\begin{array}{c}682 / 92 / \mathbf{2 5 3} \\
\mathbf{2}\end{array}$ & $\begin{array}{c}- \\
31 / 77 \\
6\end{array}$ \\
\hline Kanpanoste & & $\begin{array}{c}1003 / 118 / 22 \\
82 *\end{array}$ & $\begin{array}{c}841 / 102 / \mathbf{2} \\
\mathbf{2 8 2} *\end{array}$ & l & l & $163 / 29 / 102$ & \\
\hline $\begin{array}{l}\text { Kanpanoste } \\
\text { Goikoa }\end{array}$ & & $556 / 38 / 47$ & l & $\begin{array}{c}2158 / 164 / 1 \\
20\end{array}$ & l & $\begin{array}{c}1781 * / 136 / \\
\mathbf{1 3 9}\end{array}$ & \\
\hline Mendandia & $\begin{array}{c}196 / 15 / \\
920\end{array}$ & $\begin{array}{c}11284 / 354 / 4 \\
7679\end{array}$ & / & $\begin{array}{c}3869 / 237 / 1 \\
5562\end{array}$ & l & $\begin{array}{c}1872 / 106 / 1 \\
2518\end{array}$ & $\begin{array}{c}956 / \\
78 \\
/ 4766\end{array}$ \\
\hline La Peña & & & & 1101/130/- & I & $10 / 2 /-$ & \\
\hline Els Secans & & & & 3772/109/- & I & $2569 / 89 /-$ & \\
\hline
\end{tabular}

Please cite this article in press as: García-Martínez de Lagrán, I., et al., 8.2 ka BP paleoclimatic event and the Ebro Valley Mesolithic groups: Preliminary data from Artusia rock shelter (Unzué, Navarra, Spain), Quaternary International (2015), http://dx.doi.org/10.1016/ 
2) The quantitative increase in the faunal and lithic collections along the Mesolithic sequence, and its subsequent drop. Table 6 presents quantifications of archaeological remains: lithic remains, lithic instruments, and faunal remains. Due to the different types and quantities of published information on every context it has not been possible to realize other analyses (densities, distributions, etc.) with these variables. Nevertheless, in our opinion, these data are sufficient to show a clear trend in the intensity of Mesolithic occupation in this territory and in every site. A clear drop in these variables in the last Geometric Mesolithic contexts and the following contexts with Neolithic elements or in fully Neolithic time frames such as Atxoste or Botiquería (from 5400-5300 cal BC to 7350-7250 cal BP) (García-Martínez de Lagrán, 2014). However, in some sites this drop occurs between the first and second levels of the Geometric Mesolithic (e.g. Atxoste, Baños, Botiquería, and in the fauna of Forcas II: Fig. 11), which would have significant implications for the interpretation of this evolution. In some cases, such as Aizpea I-II, Baños 2b1-2b3sup or Botiquería 2-4, this could be due to the $8.5 \mathrm{ka}$ BP event, whereas, in others, chronology relates them to the 8.2 ka BP event: Atxoste IV-IIIb2 (Fig. 11 and Table 6).

Within this group, Artusia merits a separate comment. The evolutionary pattern of this site is different and the increase that takes place in Geometric Mesolithic 3-Artusia V is striking, although it is true that a larger surface area was excavated and, moreover, following work on Artusia IV where lithic materials were not found (Section 3.3). Another important characteristic is the drop between Artusia II and Artusia III, which could be related to the 8.5 ka BP event.

What can be deduced from these data is that, following the $8.5 \mathrm{ka} \mathrm{BP}$ event, and particularly after the $8.2 \mathrm{ka} \mathrm{BP}$ event, there is a progressive drop in the intensity of the occupation of specialised hunter-gatherer settlements. As a hypothesis, we could suggest that these consecutive events would have had several direct consequences, e.g. a possible drop in the number of available prey and, therefore, a drop in the intensity of occupation of these rock shelters dedicated mainly to hunting and related activities. That said, these pulses of dryness and cold could have altered the subsistence strategy of these groups, affecting the degree of importance of hunting, on the one hand, and gathering, on the other, in their exploitation of the environment. Similarly, the development of geometrics could have been a form of adaptation to this new more open environment which would have required fresh strategies and new technologies for projectile points. The latter likewise appear to have undergone evolution, as can be seen in Artusia and in other contexts (Utrilla-Miranda and Montes-Ramírez, 2009), possibly conditioned by the quest for greater effectiveness in hunting.

From the socio-economic point of view, it is possible that a combination of all these paleoclimatic and historical circumstances resulted in the development of some kind of social complexity among these hunter-gatherer groups. On the one hand, a period of economic growth can be appreciated in the progressive intensification of the exploitation of the territory thanks to a broad spectrum economy, both planned and diversified, as demonstrated by the increase in the variables. On the other, and coinciding with the $8.5 \mathrm{ka}$ BP and $8.2 \mathrm{ka}$ BP climate events, there may have been a crisis period. In the first case, the agency models for developing this complexity could have emerged, and, from $6550 \mathrm{cal}$ BC to $8500 \mathrm{cal}$ $\mathrm{BP}$, the management or crisis models (Arnold, 1993; Wiessner, 2002; Prentiss et al., 2007), as has recently been suggested (García-Martínez de Lagrán, 2008).
Last of all, we would like to discuss certain interpretations in relation to the Neolithisation process in this region. Occasionally, the presence in certain contexts of Neolithic elements, such as pottery, together with these environmental characteristics (fundamentally a decrease in the tree cover and the discovery of ruderal plants) has been interpreted as signs of anthropisation in the first half of the VI millennium cal BC-VIII millennium cal BP. These data would provide evidence of a Neolithisation process which would be relatively early and progressive in its evolution and chronology (e. g., Mendandia or Kanpanoste Goikoa; AldayRuiz, 2002, 2006a,b; Utrilla-Miranda and Montes-Ramírez, 2009; Alday-Ruiz et al., 2012; García-Martínez de Lagrán, 2014, 2015). In this respect, it would seem obvious, particularly in more recent levels at these sites, that the decrease in the intensity of occupation of a settlement specialising in hunting would be related to the progressive consolidation and imposition of forms of food production. Consequently, these levels are not defined as "Mesolithic with Neolithic elements" but rather as "Neolithic". Could these environmental characteristics be a continuation of the change we are suggesting from the Geometric Mesolithic (8.5 and $8.2 \mathrm{ka}$ BP events) and not a human intervention or the beginning of production practices? If that is the case, it would imply delaying the Neolithisation process and the establishment of production practices until between 5700-5600 and 5400-5300 cal BC - 7650-7550 and 7350-7250 cal BP (Rojo-Guerra et al., 2008, 2013; GarcíaMartínez de Lagrán, 2014, 2015).

\section{Acknowledgements}

The main line of research in this paper was developed within the framework of the projects "Los Caminos del Neolítico" -HAR200909027- and "Los Caminos del Neolítico II" -(HAR2013-46800-P)under directed by Dr. Manuel Rojo Guerra, granted by the Subdirectorate General for Research Projects/General Directorate of Research and Management of the National Plan for R and D and Innovation/Secretary of State for Research of the Ministry of Science and Innovation of Spain, and co-financed by the Government of Navarre. All analytical work and radiocarbon dating were carried out within the project "Origins and spread of agriculture in the western Mediterranean region" -ERC-2008-AdG 230561-, coordinated by Dr. Leonor Peña Chocarro and financed by the European Research Council. Special thanks to the Dr. Lourdes Lopez Merino for his bold effort in the search of statistically significant pollen remains. Artusia rockshelter was discovered during the survey carried out within the "Settlement and territoriality in the Pamplona area: an archaeological perspective" project developed by the University of Navarre from 1994 to 1998, and is catalogued in the Archaeological Inventory of Navarre (Inventario Arqueológico de Navarra) with the 09312380005 identification code. Iñigo GarcíaMartínez de Lagrán is a Postdoctoral researcher of the DEUI Programme of the Basque Government, Spain.

\section{References}

Alday-Ruiz, A., 1998. El depósito prehistórico de Kanpanoste Goikoa (Vírgala, Álava). In: Memoria de las actuaciones arqueológicas. 1992 and 1993. Memoria de yacimientos alaveses 5. Diputación Foral de Álava, Vitoria.

Alday-Ruiz, A., 2002. Las unidades industriales mesolíticas en la Alta-Media Cuenca del Ebro. Complutum 13, 19-50.

Alday-Ruiz, A., 2006a. El legado arqueológico de Mendandia: Los modos de vida de los últimos cazadores en la Prehistoria de Treviño. Memorias Arqueología en Castilla y León 15, Junta de Castilla y León, Valladolid.

Alday-Ruiz, A (Ed), 2006b. El Mesolítico de Muescas y Denticulados en la cuenca del Ebro y el litoral mediterráneo peninsular. Diputación Foral de Álava, Vitoria.

Alday-Ruiz, A., 2006c. El Mesolítico de Muescas y Denticulados en la cuenca del Ebro y el litoral mediterráneo peninsular: síntesis de los datos. In: Alday- 
Ruiz, A. (Ed.), El Mesolítico de Muescas y Denticulados en la cuenca del Ebro y el litoral mediterráneo peninsular. Diputación Foral de Álava, Vitoria, pp. 303-317.

Alday-Ruiz, A., Cava-Almuzara, A., 2009. El Mesolítico Geométrico en Vasconia. In: Utrilla-Miranda, P., Montes-Ramírez, L. (Eds.), El Mesolítico Geométrico en la Penísnula Ibérica, Monografías Arqueológicas, vol. 44. Universidad de Zaragoza, Zaragoza, pp. 93-129.

Alday-Ruiz, A., Castaños, P., Perales, U., 2012. Quand ils ne vivaient pas seulement de la chasse: preuves de domestication ancienne dans les gisements néolithiques d'Atxoste et de Mendandia (Pays Basque). L'Anthropologie 116, 127-147.

Alley, R.B., Agústsdóttir, A.M., 2005. The 8k event: cause and consequences of a major Holocene abrupt climate change. Quaternary Science Reviews 24, 1123-1149.

Andrews, J.E., 2006. Paleoclimate records from stable isotopes in riverine tufas: synthesis and review. Earth Science Reviews 75, 85-104.

Antolín-Tutusaus, F., Caruso, L., Mensua, C., Olària, C., Piqué, R., Alonso Martínez, N., 2010. Forest resources exploitation in the Late Mesolithic and Early Neolithic site of Cova Fosca (Ares del Maestre, Castelló, Spain). In: Delhon, C., Théry-Parisot, I., Thiébault, S. (Eds.), Des Hommes et des Plantes. Exploitation du milieu et gestion des resources végétales de la Préhistoire à nos jours, XXX rencontres internationales d'archéologie et d'histoire d'Antibes, Antibes, pp. 317-327.

Arnold, J.E., 1993. Labor and the rise of complex hunter-gatherers. Journal of Anthropological Archaeology 12, 75-119.

Aura-Tortosa, J., Carrión, Y., Estrelles, E., Jordà, G., 2005. Plant economy of huntergatherer groups at the end of the last Ice Age: plant macroremains from the cave of Santa Maira (Alacant, Spain) ca. 12000-9000 b.p. Vegetation History and Archaeobotany 14 (4), 542-550.

Barandiarán-Maestu, I., 1978. El abrigo de Botiquería dels Moros. Mazaleón (Teruel). Excavaciones arqueológicas de 1974. Cuadernos de Prehistoria y Arqueología Castellonenses 5, 49-138.

Barandiarán-Maestu, I., Cava-Almuzara, A., 1989. La ocupación prehistórica del abrigo de Costalena (Maella, Zaragoza). In: Colección Arqueología y Paleontología 6, Serie Arqueología Aragonesa.

Barandiarán-Maestu, I., Cava-Almuzara, A., 2000. A propósito de unas fechas del Bajo Aragón: reflexiones sobre el Mesolítico y el Neolítico en la cuenca del Ebro. In: SPAL: Revista de Prehistoria y Arqueología de la Universidad de Sevilla, vol. 9, pp. 293-326.

Barandiarán-Maestu, I., Cava-Almuzara, A., 2001. Cazadores-Recolectores en el Pirineo navarro. El sitio de Aizpea entre 8000 y el 6000 años antes de ahora. Universidad del País Vasco, Veleia Serie Mayor, Vitoria, p. 10.

Berger, J.-F., Guilaine, J., 2009. The 8200 cal BP abrupt environmental change and the Neolithic transitions: a Mediterranean perspective. Quaternary International 200, 31-49.

Castaños-Ugarte, P.M., 2006. Estudio arqueozoológico de la fauna de Mendandia (Sáseta, Treviño. In: Alday, A. (Ed.), El legado arqueológico de Mendandia: Los modos de vida de los últimos cazadores en la prehistoria de Treviño, pp. 435-455.

Cava-Almuzara, A., 2004a. Los "procesos culturales" del comienzo del Holoceno en la Cuenca del Ebro y su contextualización”. Salduie 4, 17-40.

Cava-Almuzara, A., 2004b. Kanpanoste (Vírgala, Álava). La ocupación prehistórica de Kanpanoste en el contexto de los cazadores-recolectores del Mesolítico. In: Memoria de yacimientos alaveses 9. Diputación Foral de Álava, Vitoria.

Cava-Almuzara, A., Beguiristain, M.A., 1991-1992. El yacimiento prehistórico del abrigo de La Peña (Marañón, Navarra). Trabajos de Arqueología Navarra 10, 69-135.

Costa-Tenorio, M., Morla Juaristi, C., Sainz Ollero, H. (Eds.), 2005. Los bosques ibéricos. Una interpretación geobotánica. Editorial Planeta, Barcelona.

Crezzini, J., Boschin, F., Bocato, P., Wierer, U., 2014. Wild cats and cut marks: exploitation of Felis silvestris in the Mesolithic of Galgenbühel/Dos de la Forca (South Tyrol, Italy). Quaternary International 330, 52-60.

Dabkowski, J., 2014. High potential of calcareous tufas for integrative multidisciplinary studies and prospects for archaeology in Europe. Journal of Archaeological Science 52, 72-83.

Floristán-Samanes, A., 1995. Geografía de Navarra. El solar-2 (Pamplona).

García-Amorena, I., Wagner, F., Gómez, F., van Hoof, T.B., García Álvarez, S., Visscher, $\mathrm{H} .$, 2008. $\mathrm{CO}_{2}$ radiative forcing during the Holocene thermal maximum revealed by stomatal frequency of Iberian oak leaves. Biogeosciences Discussion 5, 3945-3964.

García-Argüelles Andreu, P., Fullola-Pericot, J.M., 2006. La Cueva del Parco (Alòs de Balaguer, Lleida) y el Abrigo del Filador (Margalef de Montsant, Tarrafona): dos secuencias clave para el conocimiento del Epipaleolítico en el Nordeste peninsular. In: Alday-Ruiz, A. (Ed.), El Mesolítico de Muescas y Denticulados en la cuenca del Ebro y el litoral mediterráneo peninsular. Diputación Foral de Álava, Vitoria, pp. 121-133.

García-Martínez de Lagrán, I., 2008. La cuestión de la complejidad socioeconómica en las comunidades de cazador-recolector mesolíticas de la cuenca Alta y Media del Ebro. Trabajos de Prehistoria 65 (2), 49-71.

García-Martínez de Lagrán, I., 2012. El proceso de neolitización en la Interior Peninsular: la Submeseta Norte y el Alto Valle del Ebro. In: El análisis de la cerámica como herramienta interpretativa. http://uvadoc.uva.es/handle/10324/ 1707.

García-Martínez de Lagrán, I., 2014. La neolitización de la Meseta norte y de la Alta y Media cuenca del Ebro (España): premisas teóricas, análisis del registro y planteamiento de hipótesis. Zephyrus LXXIII, 83-107.

García-Martínez de Lagrán, I., 2015. The far west: recent data and approaches on the Neolithization of the Iberian Peninsula. European Journal of Archaeology 18 (3), 429-453.
Gibaja-Bao, J.F., Palomo-Pérez, A., 2004. Geométricos usados como proyectiles. Implicaciones económicas, sociales e ideológicas en sociedades neolíticas de VI-IV milenio cal BC en el noreste de la Península Ibérica. Trabajos de Prehistoria 61 (1), 81-97.

González-Amuchastegui, M.J., Serrano, E., 2013. Acumulaciones tobáceas y evolución del paisaje: cronología y fases morfogenéticas en el Alto Ebro (Burgos). Cuaternario y Geomorfología 27, 9-32.

González-Amuchastegui, M.J., Serrano, E., 2015. Tufa buildups, landscape evolution and human impact during the Holocene in the Upper Ebro Basin. Quaternary International 364, 54-64.

González-Martín, J.A., González-Amuchastegi, Ma., J. (Eds.), 2014. Las tobas en España. Sociedad Española de Geomorfología.

González-Sampériz, P. Valero, B.L., Moreno, A., Morellón, M. Navas, A., Machín, J. Delgado, A., 2008. Vegetation changes and hydrological fluctuations in the Central Ebro Basin (NE Spain) since the Late Glacial period: Saline lake records. Palaeogeography, Palaeoclimatology, Palaeoecology 259, 157-181.

González-Sampériz, P., Utrilla, P., Mazo, C., Valero-Garcés, B., Sopena, M.C., Morellón, M., Sebastián, M., Moreno, A., Martínez-Bea, M., 2009. Patterns of human occupation during the early Holocene in the Central Ebro Basin (NE Spain) in response to the 8.2 ka climatic event. Quaternary Research 71, $121-132$.

Ibarra, Y., Corsetti, F.A., Feakins, S.J., Rhodes, E.J., Kirby, M.E., 2015. Fluvial tufa evidence of Late Pleistocene wet intervals from Santa Barbara, California, U.S.A. Palaeogeography, Palaeoclimatology, Palaeoecology 422, 36-45.

Iriarte-Chiapusso, M.J., 1998. 6. - Análisis palinológico del depósito arqueológico de Kanpanoste Goikoa (Vírgala, Álava). In: Alday-Ruiz, A. (Ed.), El depósito prehistórico de Kanpanoste Goikoa (Vírgala, Alava). Memoria de las actuaciones arqueológicas. 1992 y 1993. Memoria de yacimientos alaveses 5. Diputación Foral de Álava, Vitoria, pp. 85-91.

Iriarte-Chiapusso, M.J., 2006. El entorno vegetal del abrigo de Mendandia y su depósito arqueológico: Análisis polínico. In: Alday-Ruiz, A. (Ed.), El legado arqueológico de Mendandia: los modos de vida de los últimos cazadores en la Prehistoria de Treviño. Arqueología en Castilla y León 15. Junta de Castilla y León, Valladolid, pp. 405-418.

Kobashi, T., Severinghaus, J.P., Brook, E.J., Barnola, J.M., Grachev, A.M., 2007. Precise timing and characterization of abrupt climate change 8,200 years ago from air trapped in polar ice. Quaternary Science Reviews 26, 1212-1222.

López-García, P., López-Sáez, J.A., Sánchez-Villapadierna, J.J., 1991. Análisis polínico del yacimiento de Botiquería (Mazaleón, Teruel). Trabajos de Prehistoria 48 395-403.

López-González, G., 2004. Guía de los árboles y arbustos de la Península Ibérica y Baleares. Mundi-Prensa, Madrid.

López-Sáez, J.A., López, L., Pérez, S., 2008. Crisis climáticas en la Prehistoria de la Península Ibérica: el evento 8200 cal. BP como modelo. In: Rovira, S., GarcíaHeras, M., Gener, M., Montero, I. (Eds.), VII Congreso Ibérico de Arqueometría. C.S.I.C., Madrid, pp. 77-86.

Martínez-Moreno, J., Mora-Torcal, R., Casanova-Martí, J., 2006. El Mesolítico de los Pirineos surorientales: una reflexión sobre el signficado de las "facies de fortuna" del Postglaciar. In: Alday-Ruiz, A. (Ed.), El Mesolítico de Muescas y Denticulados en la cuenca del Ebro y el litoral mediterráneo peninsular. Diputación Foral de Álava, Vitoria, pp. 163-190.

Montes-Ramírez, L., Utrilla, P., Mazo, C., 2006. El Epipaleolítico macrolítico en Aragón en el contexto del Valle del Ebro y la Cataluña costera. In: Alday-Ruiz, A (Ed.), El Mesolítico de Muescas y Denticulados en la cuenca del Ebro y el litoral mediterráneo peninsular. Diputación Forral de Álava, Vitoria, pp. 193-219.

Moreno-Caballud, A., López Merino, L., Leira, M., Barba, J., González Sampériz, P. Valero, B.L., López Saez, J.A., Santos, L., Mata, M.P., Ito, E., 2011. Revealing Holocene environmental history from multiproxy record of a mountain lake (Lago Enol, N Iberian Peninsula). Journal of Paleolimnology 46 (3), 327-349.

Muñoz-Sobrino, C., Ramil Rego, P., Gómez Orellana, P., Ferreiro da Costa, J., Díaz, A. 2009. Climatic and human effects on the post-glacial dynamics of Fagus sylvatica L. in NW Iberia. Plant Ecology 203, 317-340.

Pedley, H.M., 1990. Classification and environmental models of cool freshwater tufas. Sedimentary Geology 68, 143-154.

Pedley, M., 2009. Tufas and travertines of the Mediterranean region: a testing ground for freshwater carbonate concepts and developments. Sedimentology $56,221-246$

Pentecost, A., 2005. Travertine. Springer, Berlin.

Peñalba, C., 1992. La vegetación y el clima en los Montes Vascos durante el Pleistoceno superior y el Holoceno según los análisis polínicos. In: Cearreta y, A. Ugarte, F.M. (Eds.), The Late Quaternary in the Western Pyrenean Region. Universidad del País Vasco, Bilbao, pp. 171-182.

Pérez-Díaz, S., 2012. El paisaje vegetal durante la Prehistoria reciente en la vertiente mediterránea de Euskal Herria. https://addi.ehu.es/handle/10810/10805.

Pérez-Jordà, G., 2010. Estudio paleocarpológico del Cingle del Mas Cremat. In: Vicente Gabarda, M. (Ed.), El Cingle del Mas Cremat (Portell de Morella, Castellón). Un asentamiento en altura con ocupaciones del Mesolítico Reciente al Neolítico Final. Renomar S.L.EIN Mediterráneo S.L., València, pp. $147-156$

Prentiss, A.M., Lyons, N., Harris, L.E., Burns, M.R.P., Godin, T.M., 2007. The emergence of status inequality in intermediate scale societies: a demographic and socioeconomic history of the Keatley Creek site, British Columbia. Journal of Anthropological Archaeology 26, 299-327.

Rivera, D., Obón, C., 1991. La guía INCAFO de las plantas útiles y venenosas de la Península Ibérica y Baleares (excluídas medicinales). INCAFO, Madrid. 
Rodanés-Vicente, J.M., Picazo Millán, J.V., 2009. La cabaña mesolítica del Cabezo de La Cruz (La Muela, Zaragoza). In: Utrilla-Miranda, P., Montes-Ramírez, L. (Eds.) El Mesolítico Geométrico en la Península Ibérica, Monografías Arqueológicas, vol. 44. Universidad de Zaragoza, Zaragoza, pp. 327-342.

Rojo-Guerra, M.A., Kunst, M., Garrido-Pena, R., García-Martínez de Lagrán, I., Morán-Dauchez, G., 2008. Paisajes de la Memoria: asentamientos del Neolítico antiguo en el Valle de Ambrona (Soria, España). Servicio de Publicaciones de la Universidad de Valladolid, Valladolid.

Rojo-Guerra, M., Peña, L., Royo, J.I., Tejedor, C., García, I., Arcusa, H., Garrido, R. Moreno, M., Mazzuco, N., Gibaja, J.F., Ortega, D., Kromer, B., Alt, K., 2013. Pastores trashumantes del Neolítico antiguo en un entorno de alta montaña: secuencia crono-cultural de la Cova de Els Trocs (San Feliú de Veri, Huesca). Boletín del Seminario de Arte y Arqueología LXXIX, 9-55.

Rojo-Gerra, M., Royo, J.I., Garrido Pena, R., García Martínez de Lagrán, I., Tejedor, C., Arcusa, H., García Gazolaz, J., Sesma, J., Beguiristaín, M.A., 2012. Los caminos del Neolítico: un proyecto de investigación en el Valle del Ebro, Rubricatum. Revista del Museu de Gavà 5, 43-50.

Ruiz-Alonso, M., 2014. Evolución y explotación de los recursos vegetales desde e Tardiglaciar en la Vertiente Mediterranea del País Vasco: datos antracológicos (PhD thesis). Universidad del País Vasco, Vitoria-Gasteiz.

Sánchez-Goñi, M.F., 2004. La vegetación contemporánea de los grupos Meso-Neolíticos y Neo-Calcolíticos de Kanpanoste (Vírgala, Álava). In: Cava, A. (Ed.), Kanpanoste (Virgala, Álava), la ocupación prehistórica de Kanpanoste en el contexto de los cazadores-recolectores del Mesolítico, Serie Monografias de Yacimientos Alaveses. Diputación Foral de Álava, Vitoria-Gasteiz, pp. 161-168.

Sancho, C., Peña, J.L., Muñoz, A., Benito, G., McDonald, E., Rhodes, E.J. Longares, L.A., 2008. Holocene alluvial morphopedosedimentary record and environmental changes in the Bardenas Reales Natural Park (NE Spain). Catena $73,225-238$.

Torroba-Balmori, P. Zaldívar, P., Hernández Lázaro, Á. 2013. Semillas de frutos carnosos del norte ibérico: guía de identificación. Ediciones Universidad de Valladolid, Valladolid.

Utrilla-Miranda, P., Mazo, C., 2014. La Peña de las Forcas (Graus, Huesca). Un asentamiento estratégico en la confluencia del Ésera y el Isábena. In: Monografías Arqueológicas, vol. 46. Universidad de Zaragoza.

Utrilla-Miranda, P., Domingo, R., Martínez, M., 2003. La campaña del año 2002 en e Arenal de Fonseca (Ladruñán, Teruel). Salduie 3, 310-311.

Utrilla-Miranda, P., Montes-Ramírez, L. (Eds.), 2009. EL Mesolítico Geométrico en la Península Ibérica. In: Utrilla-Miranda, P., Montes-Ramírez, L. (Eds.), 2009, Monografías Arqueológicas, vol. 44. Universidad de Zaragoza.

Utrilla-Miranda, P., Montes, L., Mazo, C., Martínez Bea, M., Domingo, R., 2009. E Mesolítico geométrico en Aragón. In: Utrilla, P., Montes, L. (Eds.), El Mesolítico Geométrico en la Península Ibérica, Monografías Arqueológicas, vol. 44. Universidad de Zaragoza, pp. 131-190.
Utrilla-Miranda, P., Rodanés, J.M., 2004. Un asentamiento epipaleolítico en el valle del río Martín. El Abrigo de Los Baños (Ariño, Teruel). In: Monografías Arqueológicas, vol. 39. Universidad de Zaragoza.

Vaquer, J., Ruas, M.-P., 2009. La grotte de l'Abeurador Félines-Minervois (Hérault): occupations humaines et environnement du Tardiglaciaire à l'Holocène, De Méditerranée et d'ailleurs. Melanges offerts à Jean Guilaine, Toulouse, pp. 761-792.

Vaquero-Rodríguez, M., 2006. El Mesolítico de facies macrolítica en el centro y sur de Cataluña. In: Alday-Ruiz, A. (Ed.), El Mesolítico de Muescas y Denticulados en la cuenca del Ebro y el litoral mediterráneo peninsular. Diputación Foral de Álava, Vitoria, pp. 137-160.

Vázquez-Urbez, M., 2008. Caracterización y significado ambiental de depósitos tobáceos neógenos de la Cuenca del Ebro. Comparación con ambientes Cuaternarios (Ph. D. thesis). Universidad de Zaragoza, Spain. http://zaguan.unizar. es/record/2057/files/TESIS-2009-038.pdf.

Viles, H.A., Taylor, M.P., Nicoll, K., Neumann, S., 2007. Facies evidence of hydroloclimatic regime shifts in tufa depositional sequences from the arid Naukluft Mountains, Namibia. Sedimentary Geology 195, 39-53.

Wiessner, P., 2002. The vines of complexity: egalitarian structures and the institutionalization of inequality among the Enga. Current Anthropology 43, 233-270.

Zapata-Peña, L., 1998. La explotación del medio vegetal en Kanpanoste Goikoa (Álava): combustible y alimentación. In: Alday, Alfonso (Ed.), Kanpanoste Goikoa. Museo de Arqueología de Álava, Vitoria-Gasteiz, pp. 95-101.

Zapata-Peña, L., 2000a. Análisis de los macrorrestos vegetales de Kobeaga II: la explotación del bosque. Illunzar 4, 177-183, 98/00.

Zapata-Peña, L., 2000b. La recolección de plantas silvestres en la subsistencia mesolítica y neolítica. Datos arqueobotánicos del País Vasco. Complutum 11, 157-169.

Zapata-Peña, L., 2001. El uso de los recursos vegetales en Aizpea (Navarra, Pirineo Occidental): la alimentación, el combustible y el bosque. In: Barandiarán Maestu, I., Cava, A. (Eds.), Cazadores-recolectores en el Pirineo navarro: el sitio de Aizpea entre 8.000 y 6.000 BP, Anejos de Veleia, Series Maior, vol. 10. Universidad del País Vasco/Euskal Herriko Univertsitatea, Vitoria-Gasteiz, pp. 325-359.

Zapata-Peña, L., 2002. Origen de la agricultura en el País Vasco y transformaciones en el paisaje: Análisis de los restos vegetales arqueológicos. Kobie (Anejo 4). Diputación Foral de Bizkaia, Bilbao.

Zapata-Peña, L., 2012. Holocene wood charcoal from El Mirón cave. Vegetation and wood use. In: Straus, L.G., González Morales, M.R. (Eds.), El Mirón Cave. Cantabrian Spain. The Site and its Holocene Archaeological Record. University of New Mexico, Alburquerque, pp. 174-196.

Zapata-Peña, L., Peña-Chocarro, L., 2005. Los macrorrestos vegetales del yacimiento de Mendandia. In: Alday, A. (Ed.), El campamento prehistórico de Mendandia: ocupaciones mesolíticas y neolíticas entre el 8500 y el 6400 B.P. Colección Barandiarán 9. Fundación J.M. Barandiarán/Diputación Foral de Álava, Vitoria, pp. 411-425. 